\title{
Current Status of Environmental, Health, and Safety Issues of Electrochemical Capacitors for Advanced Vehicle Applications
}

Laura J. Vimmerstedt and Carol J. Hammel

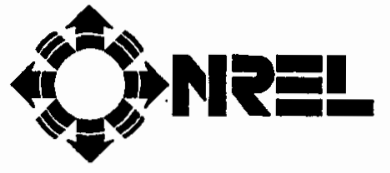

National Renewable Energy Laboratory 1617 Cole Boulevard Golden, Colorado 80401-3393

A national laboratory of the U.S. Department of Energy Managed by Midwest Research Institute under Contract No. DE-AC36-83CH10093

Prepared under Task No. AS015702 


\section{NOTICE}

This report was prepared as an account of work sponsored by an agency of the United States govemment. Neither the United States govemment nor any agency thereof, nor any of their employees, makes any warranty, express or implied, or assumes any legal liability or responsibility for the accuracy, completeness, or usefulness of any information, apparatus, product, or process disclosed, or represents that its use would not infringe privately owned rights. Reference herein to any specific commercial product, process, or service by trade name, trademark, manufacturer, or otherwise does not necessarily constitute or imply its endorsement, recommendation, or favoring by the United States govemment or any agency thereof. The views and opinions of authors expressed herein do not necessarily state or reflect those of the United States govemment or any agency thereof.

Available to DOE and DOE contractors from:

Office of Scientific and Technical Information (OSTI)

P.O. Box 62

Oak Ridge, TN 37831

Prices available by calling (423) 576-8401

Available to the public from:

National Technical Information Service (NTIS)

U.S. Department of Commerce

5285 Port Royal Road

Springfield, VA 22161

(703) $487-4650$ 


\section{Preface}

The electrochemical capacitor is a candidate advanced vehicle technology. Current development efforts target using electrochemical capacitors to provide power assists in hybrid electric vehicles (HEVs). HEVs could help meet national transportation energy and environmental goals because of their improved fuel efficiency and emissions as compared to conventional vehicles. Electrochemical capacitors might be used in HEVs because of their high power capability and long life. Understanding environmental, health, and safety (EH\&S) issues associated with electrochemical capacitors in advanced vehicles is an important step toward their commercialization. This report examines the EH\&S issues associated with the use of electrochemical capacitors in advanced vehicles.

The National Renewable Energy Laboratory (NREL) prepared this report for the Office of Advanced Automotive Technologies of the Office of Transportation Technologies in the U.S. Department of Energy (DOE). The report is intended to help DOE determine the direction of its research, development, and demonstration program for electrochemical capacitor technology, and is part of DOE's program for working with industry to commercialize electrochemical capacitors for advanced vehicles. Previous EH\&S reports were prepared by NREL for sodium-sulfur, nickel metal-hydride, lithium solid polymer electrolyte, and lithiumion electric vehicle batteries. The assessment of EH\&S issues for advanced energy storage systems in vehicles is ongoing; future studies will build on this and previous analyses.

We wish to thank the many members of the electrochemical capacitor research and development community who generously offered their expertise. We thank Tim Murphy of Idaho National Engineering Laboratory for his guidance on electrochemical capacitor research. We thank Andy Altemos, who played a key role in the shipping regulations analysis. We would also like to thank Pat Davis, Ken Heitner, and Bob Helton of DOE for their leadership and support in directing and sponsoring the EH\&S program and the various studies of program issues. 


\section{Executive Summary}

Electrochemical capacitors are being developed for advanced vehicles. The primary focus of current development is the application of these devices as power assists in hybrid electric vehicles (HEVs). They are expected to achieve higher power and longer life than batteries, possibly making them a useful supplement to battery packs in electric vehicles and HEVs. Use in HEVs (vehicles with propulsion systems using a combination of batteries and an engine) is more likely than in electric vehicles. In HEV applications, the capacitor would provide additional power during acceleration. Improving electrochemical capacitor performance for these possible applications is an ongoing research and development (R\&D) effort. In addition, developing advanced technologies for HEVs furthers the goals of increasing vehicle fuel efficiency and decreasing emissions.

As with many developing technologies, there is uncertainty regarding which materials will be used in electrochemical capacitors for advanced vehicles. This report reviews materials presented in the open literature, or discussed in personal communication with R\&D personnel.

The electrochemical capacitors considered in this report use carbon-based electrodes and nonaqueous or aqueous electrolytes. Activated carbon, activated carbon fibers, or carbon foam are the electrode materials; propylene carbonate with co-solvents and tetra-alkyl ammonium salts are likely to be used as the nonaqueous electrolyte; and sulfuric acid or potassium hydroxide are likely aqueous electrolytes. Other types of electrochemical capacitors not considered in this report include devices with inorganic solid or molten salt electrolytes, mixed metal-oxide-based capacitors, and devices using other forms of carbon. This report presents health and safety issues, environmental issues, and shipping requirements for carbon-based electrochemical capacitors for advanced vehicles.

The health and safety issues chapter includes safety status, intrinsic material hazards, and mitigation of material hazards. Discussion of these issues is not meant to imply that commercial capacitors for vehicles would have health and safety problems, nor does this report rank hazards of electrochemical capacitors compared to other energy storage systems. Most of the health and safety issues would arise during manufacturing, disposal, or accidental destruction of devices, not during their normal use in vehicles.

For normally operating capacitors, electrical hazards and hazards from mechanical abuse would be the primary concerns. Normal operation would not expose the user to significant thermal burns or material hazards. High-voltage hazards of large electrochemical capacitors would be similar to those of large batteries. Because shock and burn hazards of high voltage have been addressed in detail elsewhere, they will not be examined in this report. Other electrical hazards include overvoltage and short circuit. Mechanical hazards could occur if mechanical abuse caused a short circuit.

Intrinsic material hazards include bone damage from fluoride salts, irritation to eyes and skin from borates, organic salts, and solvents, and irritation to lungs upon inhalation of dusts, such as carbon

dust. Nickel, a confirmed human carcinogen, could be used as an electrode additive or current collector. 
Material hazards are mitigated when capacitors are designed for reliable performance. For example, appropriate electrical circuits and containment are needed to ensure adequate performance, and simultaneously protect users against capacitor materials and hazardous electrochemical reactions. Another important performance factor, thermal management, also mitigates hazards of overheated or unevenly heated capacitors.

Workplace exposure to material hazards of electrochemical capacitors could also occur. The Occupational Safety and Health Administration (OSHA) regulates permissible exposure limits for some of the possible materials. As required by OSHA regulations, these hazards would be mitigated using such workplace practices as ventilation and dust management.

The environmental regulations that could apply to electrochemical capacitors were also assessed. Environmental regulations must be considered during the development of new energy storage technologies. Electrochemical capacitor manufacturing may produce water emissions, air emissions, and solid waste subject to United States Environmental Protection Agency (EPA) regulations under the Clean Water Act (CWA), Clean Air Act (CAA), and the Resource Conservation and Recovery Act (RCRA).

In addition to these environmental, health, and safety (EH\&S) issues, shipping requirements for electrochemical capacitors are considered. Certain types of electrochemical capacitors are not subject to hazardous material shipping requirements. The report reviews the conditions under which electrochemical capacitors would be excepted, and the regulations that would apply to electrochemical capacitors not meeting these conditions.

The main factors that determine shipping requirements are whether the capacitor is charged, whether it has free electrolyte, and whether the electrolyte is regulated as a hazardous material. These factors may be controlled, in part, by the manufacturer or party offering the device for transport. For example, the state of charge, quantity of electrolyte, and electrolyte composition could be selected to reduce the regulatory burden of shipping requirements.

This assessment should assist electrochemical capacitor and advanced vehicle developers, government funding agencies, and government regulatory agencies in understanding and mitigating EH\&S hazards that might result from use of electrochemical capacitors in advanced vehicles. 


\section{Table of Contents}

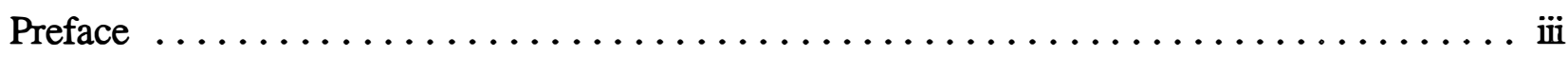

Executive Summary $\ldots \ldots \ldots \ldots \ldots \ldots \ldots \ldots \ldots \ldots \ldots \ldots \ldots \ldots \ldots \ldots \ldots$ iv

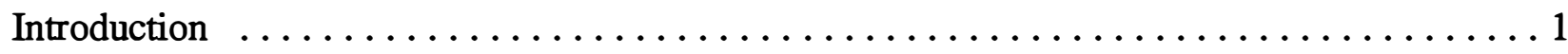

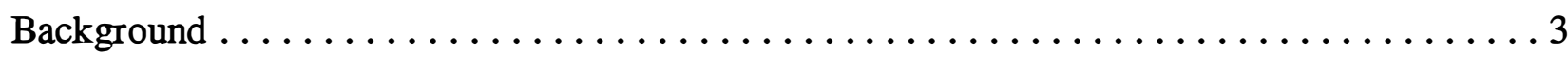

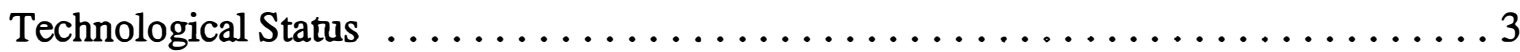

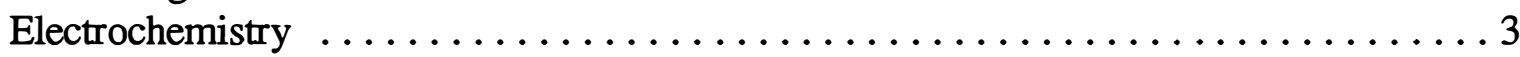

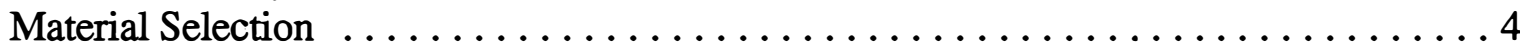



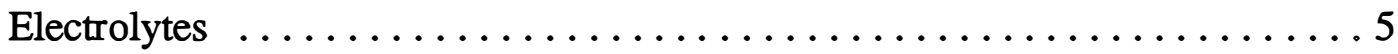

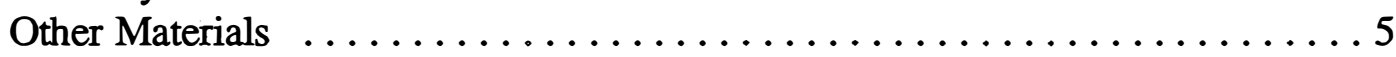

Health and Safety Issues $\ldots \ldots \ldots \ldots \ldots \ldots \ldots \ldots \ldots \ldots \ldots \ldots \ldots \ldots$



Electrical Hazards . . . . . . . . . . . . . . . . . . . . . . . . 8

Mechanical Hazards $\ldots \ldots \ldots \ldots \ldots \ldots \ldots \ldots \ldots \ldots$

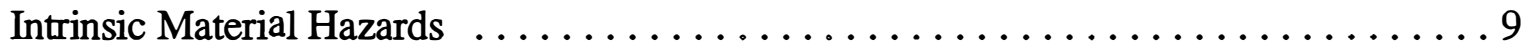



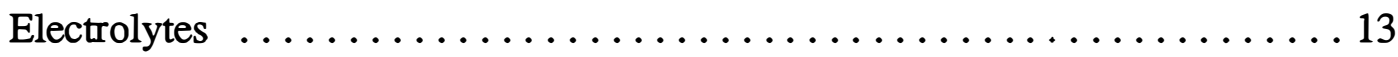



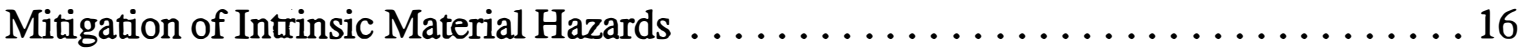

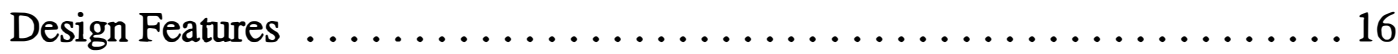

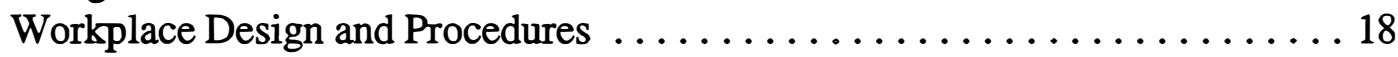

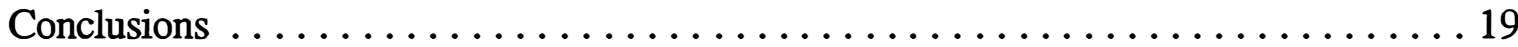

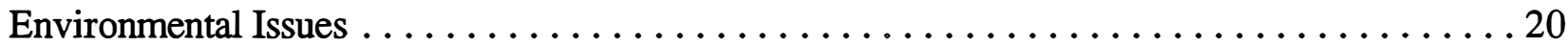

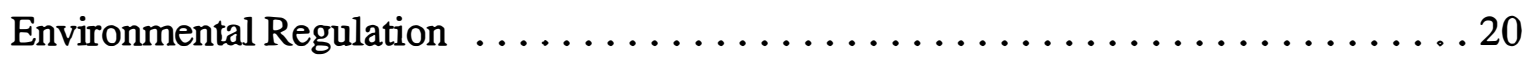

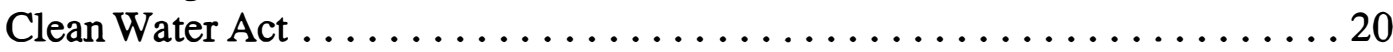

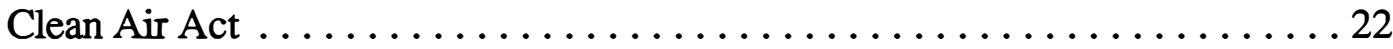

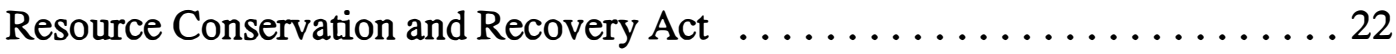

Waste Minimization . . . . . . . . . . . . . . . . . . . . . . 24

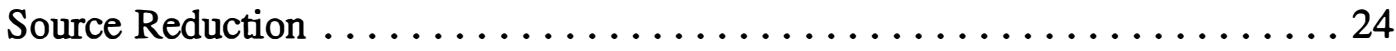



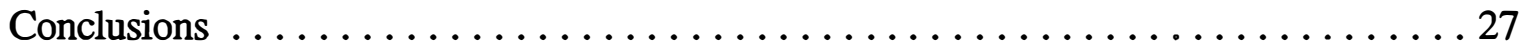

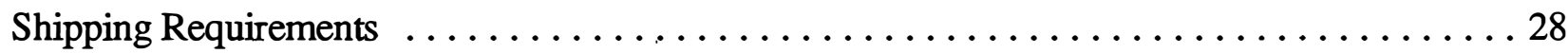



Mitigating Hazards of Forbidden Materials and Devices . . . . . . . . . . . 28

Determining Other Transportation Requirements $\ldots \ldots \ldots \ldots \ldots \ldots \ldots$ 
Electrolyte Hazards . . . . . . . . . . . . . . . . . . . . . . 29

Electrolyte Quantity . . . . . . . . . . . . . . . . . . . . . 30

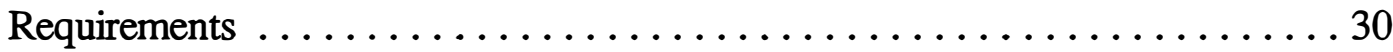

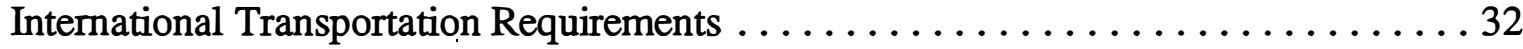

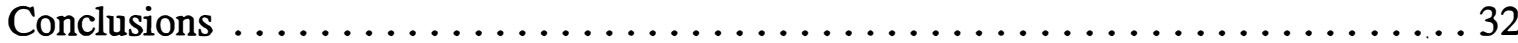

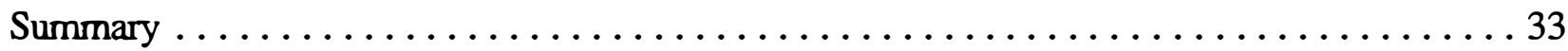

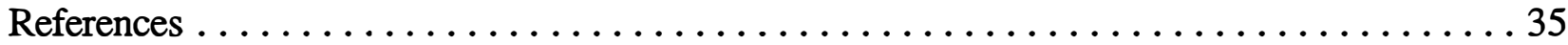

Appendix A. Hazardous Materials Transport Regulations $\ldots \ldots \ldots \ldots \ldots \ldots \ldots \ldots 41$

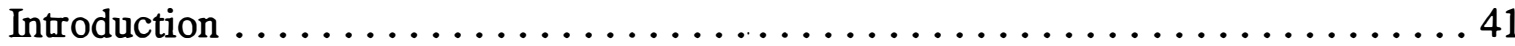

Domestic Transportation Requirements $\ldots \ldots \ldots \ldots \ldots \ldots \ldots \ldots \ldots \ldots \ldots, \ldots \ldots \ldots$

Materials and Devices Forbidden in Transportation . . . . . . . . . 42

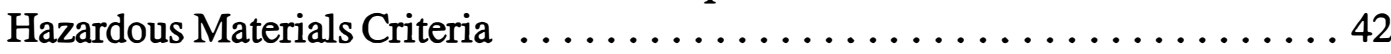

Hazardous Materials Table . ....................... 43

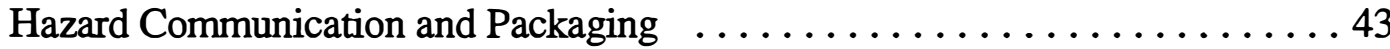

International Transportation Requirements $\ldots \ldots \ldots \ldots \ldots \ldots \ldots \ldots \ldots . \ldots \ldots$ 


\section{List of Figures}

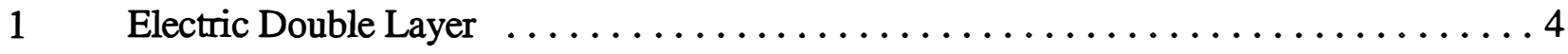

2 Separation Phase of Lead-Acid Battery Recycling Process $\ldots \ldots \ldots \ldots \ldots \ldots 26$

\section{List of Tables}

1 Status of Electrochemical Capacitor Technology $\ldots \ldots \ldots \ldots \ldots \ldots \ldots \ldots$

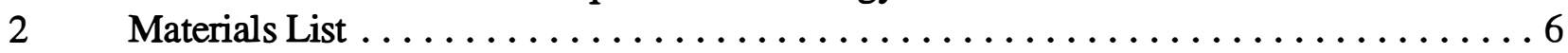






\section{List of Acronyms}

ACGIH $\ldots . \ldots \ldots \ldots . . .$. American Conference of Governmental and Industrial Hygienists

BEI

Biological Exposure Index

CAA

Clean Air Act

CFR Code of Federal Regulations

CWA

Clean Water Act

DEC diethyl carbonate

$\mathrm{DMC}$ dimethyl carbonate

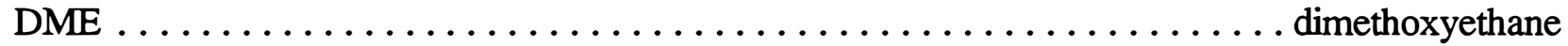

DOT $\ldots \ldots \ldots \ldots \ldots \ldots \ldots \ldots \ldots \ldots \ldots \ldots \ldots$ Department of Transportation

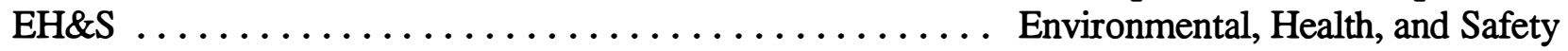

EPA $\ldots \ldots \ldots \ldots \ldots \ldots \ldots \ldots \ldots \ldots \ldots \ldots \ldots \ldots \ldots \ldots \ldots \ldots$ Environmental Protection Agency

EPRI $\ldots \ldots \ldots \ldots \ldots \ldots \ldots \ldots \ldots \ldots \ldots \ldots \ldots \ldots \ldots \ldots$ Electric Power Research Institute

ICAO $\ldots \ldots \ldots \ldots \ldots \ldots \ldots \ldots \ldots \ldots \ldots \ldots \ldots \ldots \ldots \ldots \ldots$ International Civil Aviation Organization

IMO $\ldots \ldots \ldots \ldots \ldots \ldots \ldots \ldots \ldots$ International Maritime Organization

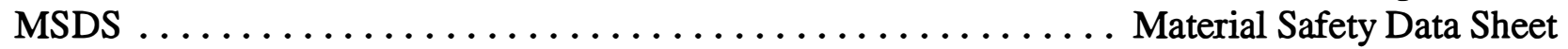

NPDES . . . . . . . . . . . . National Pollutant Discharge Elimination System

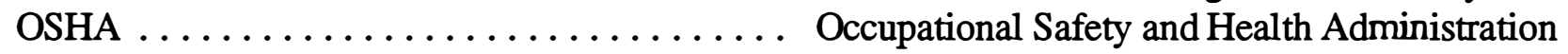

PAN $\ldots \ldots \ldots \ldots \ldots \ldots \ldots \ldots \ldots \ldots \ldots \ldots \ldots \ldots \ldots \ldots \ldots \ldots \ldots \ldots \ldots \ldots \ldots \ldots \ldots$ polyacrylonitrile

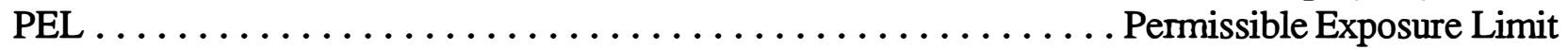

POTW $\ldots \ldots \ldots \ldots \ldots \ldots \ldots \ldots \ldots$ Publicly Owned Treatment Wo. . . . . . . . . . . .

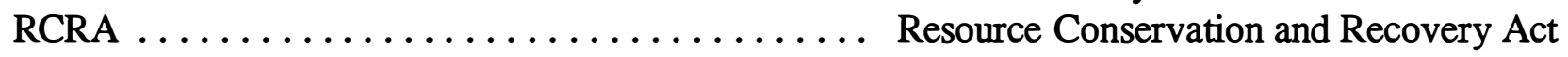

STEL $\ldots \ldots \ldots \ldots \ldots \ldots \ldots \ldots \ldots \ldots \ldots \ldots \ldots \ldots \ldots \ldots \ldots \ldots$ Short Term Exposure Limit

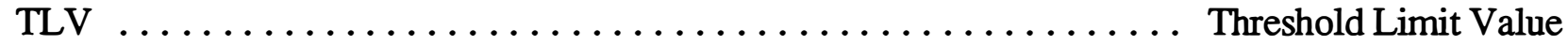

Triflate $\ldots \ldots \ldots \ldots \ldots \ldots \ldots$ trifluoromethanesulfonate

TSCA ............................ Toxic Substances Control Act

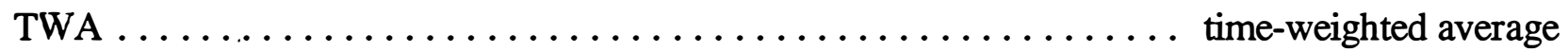

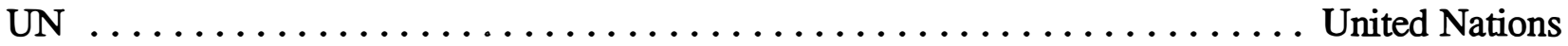




\section{Introduction}

Electrochemical capacitors are under investigation for use in advanced electric and hybrid electric vehicles (EVs and HEVs). Electrochemical capacitors are primarily being considered as power assists in HEVs, but they are not yet commercially available for this purpose. Although R\&D is primarily focussed on HEVs, this new technology might provide greater power and longer cycle life than candidate battery technologies for both EVs and HEVs. Electrochemical capacitors could also serve several other functions in advanced vehicles, such as load leveling high-energy batteries, powerconditioning electronics, catalytic converter preheating, and engine starting.

The types of electrochemical capacitors considered in this report are carbon-based electrode technologies with nonaqueous or aqueous electrolytes. These technologies are candidates for HEV power assists, which could make an important contribution to the technological and economic feasibility of HEV propulsion systems. Because environmental, health, and safety (EH\&S) issues are an important consideration in developing and commercializing electrochemical capacitors for advanced vehicles, this report will provide a preliminary assessment of these issues for certain devices. The purpose of this EH\&S assessment is to help electrochemical capacitor and vehicle developers, government funding agencies, and government regulatory agencies to identify and address EH\&S issues. Previous reports characterized EH\&S issues of advanced batteries in electric vehicle applications.

In order to determine the EH\&S issues for these technologies, the materials used must be identified. The electrochemical capacitors considered in this report consist of carbon-based electrodes and either a nonaqueous or an aqueous electrolyte. Although other types of electrochemical capacitors are being studied, this type of technology may be the strongest near-term candidate for power assists in HEVs. The electrodes are made of high-surface-area carbon, which may be prepared in various ways and may contain additives. The nonaqueous electrolyte can be made of various salts dissolved in various organic liquids; sulfuric acid or potassium hydroxide are used for the aqueous electrolyte.

This report relies on information in the open literature and on personal communication, rather than on proprietary research and development (R\&D) information. The commercial construction of electrochemical capacitors for vehicle power assists was not reported in the open literature as of May 1996, although related commercial devices for other uses are available. Therefore, this report relies on the information available about laboratory devices, prototypes of devices for vehicles, and commercial devices intended for other purposes. The final designs and materials of commercial electrochemical capacitors for advanced vehicles may differ from those considered here. Therefore, these designs may pose different EH\&S issues. However, the devices considered in this report were selected because they have similar materials and designs to those of electrochemical capacitors proposed for HEV power assists.

Companies in the United States, Japan, and Europe are developing electrochemical capacitors for a variety of vehicle applications, including power assists. Companies actively developing this technology include Maxwell Laboratories, Evans Capacitors Company, Polystor, GE Company, 
Panasonic, NEC Corporation, Alupower Incorporated, Pinnacle Research Institute, SAFT America, Federal Fabrics-Fibers, Dornier GmbH, Asahi Glass Company Ltd., Redox, and Powercell.

U.S. govermment activities include initiatives of the U.S. Department of Energy (DOE) and the Partnership for a New Generation of Vehicles Energy Storage Technical Team. They support development of electrochemical capacitors for vehicle applications through research and development programs that include the HEV program, the Idaho National Engineering Laboratory Technical Support/Testing program, and various other government laboratory programs (Lawrence Livermore National Laboratory, Los Alamos National Laboratory, Army Research Laboratory, and Argonne National Laboratory), and the Small Business Innovation Research program and Small Business Technology Transfer programs. 


\section{Background}

This chapter will provide information on the technological status and electrochemistry of electrochemical capacitors, and the performance criteria guiding materials selection. Because electrochemical capacitor technology is still being developed, future technologies could have EH\&S characteristics that differ from those of existing devices. In any case, a basic understanding of the electrochemistry and materials of electrochemical capacitors will prove important to our a discussion of EH\&S issues.

\section{Technological Status}

This summary of technological status reflects the performance of commercial and experimental devices as measured at the INEL, as well as the goals established for the technology by DOE (see Table 1 below).

Table 1. Status and Goals for Electrochemical Capacitor Technology

\begin{tabular}{|l|l|l|l|l|}
\hline & 1996 & 1998 & 2000 & 2004 \\
\hline $\begin{array}{l}\text { Power/Energy Ratio } \\
\text { (W/Wh) }\end{array}$ & $>250$ & $>100$ & $>100$ & $>100$ \\
\hline $\begin{array}{l}\text { Specific Energy } \\
(\mathrm{Wh} / \mathrm{kg})\end{array}$ & 2.5 & 8 & 15 & 15 \\
\hline Energy Density (Wh/L) & 3 & 10 & 20 & 20 \\
\hline Cycle Life (cycles) & $>100 \mathrm{~K}$ & $250 \mathrm{~K}$ & $250 \mathrm{~K}$ & $250 \mathrm{~K}$ \\
\hline $\begin{array}{l}\text { Production Cost } \\
(\$ / \mathrm{kWh})\end{array}$ & $\mathrm{n} / \mathrm{a}$ & $\mathrm{n} / \mathrm{a}$ & 1000 & 650 \\
\hline
\end{tabular}

Source: Murphy, Wright, and Sutula 1996.

\section{Electrochemistry}

Electrochemical capacitors, which consist of a metallic surface and an ionically conducting electrolyte (Raistrick 1993), are different from conventional capacitors, which generally consist of metallic surfaces insulated from each other by a dielectric material (a solid, liquid, gas, or vacuum). When an electric field is applied to a conventional capacitor, electrostatic energy is stored at the interface between the metallic surface and the dielectric. 
Electrochemical capacitors rely on two energy storage mechanisms: double-layer capacitance and pseudocapacitance. Double-layer capacitance refers to energy storage in the electric double layer, which is the charge separation that forms at the interface between electrode and electrolyte. Figure 1 shows charge separation in two parallel capacitors. Pseudocapacitance refers to the faradaic, or oxidation and reduction, reactions that occur at the surface of the electrode. High-surface-area electrodes provide greater interface area, and therefore greater energy storage. Raistrick (1993) provides more detailed information about these two types of energy storage mechanisms in a review of energy storage in electrochemical capacitors.

During charging of an electrochemical capacitor, energy is stored in the charge separation that forms at the electrode-electrolyte interface, and in the products of nonspontaneous oxidation and reduction reactions. During discharging, this stored energy is released. Conditions of charging and discharging must be controlled to prevent electrolyte electrolysis.

Faradaic reactions in electrochemical capacitors provide greater energy density than would be available with only electric doublelayer energy storage. However, the irreversibility of these pseudo-capacitive energy storage mechanisms could reduce the cycle life of electrochemical capacitors if these mechanisms were responsible for much of the energy storage (Eisenmann 1995). In addition, faradaic reactions store and release energy at a slower rate than electric double-layer energy storage (Raistrick 1993), which could reduce the effectiveness of electrochemical capacitors in high-power applications.

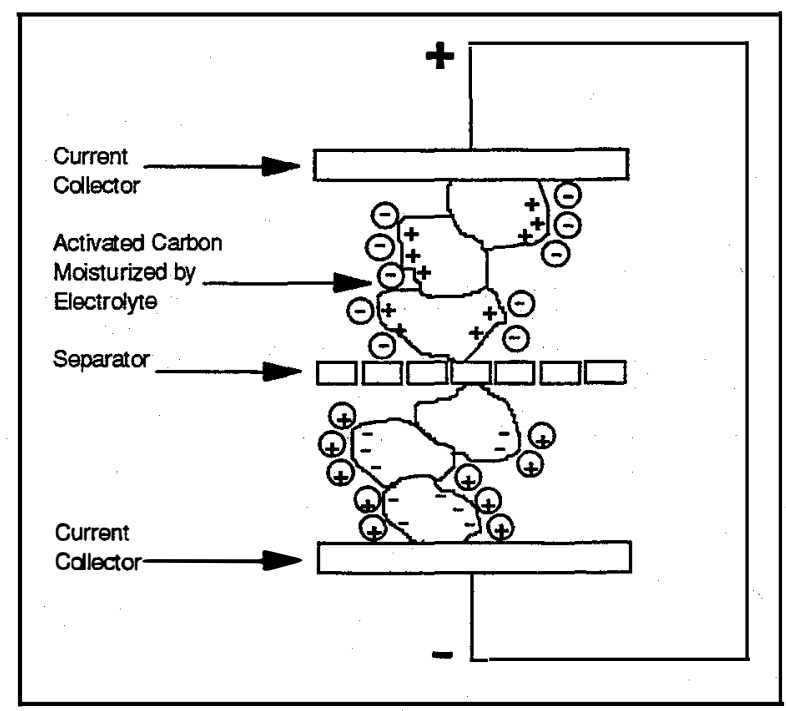

Figure 1. Electric double layer Source: Clark 1995

\section{Material Selection}

Electrochemical capacitors consist of positive and negative electrodes, electrolytes, separators, current collectors, and a case (see Table 2). The electrochemical capacitors considered in this report use carbon-based electrodes and nonaqueous or aqueous electrolytes. Other electrodes and electrolytes have been designed, including mixed metal oxide electrodes and molten salt electrolytes. These alternatives will not be considered here, because their commercialization seems likely to occur later than commercialization of the devices addressed in this report. 


\section{Electrodes}

The positive and negative electrodes are made of high-surface-area carbons, with or without additives, prepared from various feedstocks and by various methods. Electrode characteristics that are important for electrochemical capacitor performance include high usable surface area, low resistance, and speed and reversibility of faradaic reactions with the electrolyte.

A variety of techniques are used to prepare carbon materials with the desired characteristics. Activated carbon particles (Evans 1994; Y Yoshida et al. 1992), activated carbon fibers (Farahmandi and Blank 1994), and carbon foam (Mayer, Pekala, and Kaschmitter 1993) are among the materials that may be used, and will be considered in this report. All of these materials are prepared to have high usable surface areas, with pores sized appropriately for the electrolyte. In some designs, a metal, such as nickel or aluminum, is introduced to decrease the resistance within the electrode (Farahmandi et al. 1994; Farahmandi and Blank 1994).

\section{Electrolytes}

The electrolytes considered in this report are either aqueous electrolytes, or a salt dissolved in an organic liquid to form a nonaqueous electrolyte. Electrolyte performance characteristics to improve conductivity, power, energy, and life include high solubility of the salt in the liquid, high salt dissociation, size of solvated ions, viscosity, solvent dielectric constant, the size of the electrochemical potential stability window, and speed and reversibility of faradaic reactions (Conway 1994).

For the aqueous electrolyte, potassium hydroxide or sulfuric acid solution are common choices. For the nonaqueous electrolyte, propylene carbonate is a commonly used organic liquid, and tetra-alkyl ammonium salts are also likely materials. Co-solvents such as diethyl carbonate, dimethyl carbonate, and dimethoxyethane may be used to improve the characteristics of the nonaqueous electrolyte. Various other nonaqueous electrolytes are possible, but will not be considered in this report because they are less likely to be used near-term. Research on the properties of other organic liquids-such as gamma-butyrolactone - used as electrochemical capacitor electrolytes is reported in Ue (1994).

\section{Other Materials}

In addition to the electrode and electrolyte materials, other materials within an electrochemical capacitor are important for overall performance. Separators must be electrochemically stable and impermeable to electrode materials. Polypropylene, polyethylene, nylon, cellulosics, and glass fibers are among the possible separator materials. Current collectors must be conductive and corrosion resistant. Graphite, aluminum, nickel, copper, and conductive plastics are among the materials that may be used. Other materials are selected for their strength, low weight, and durability, such as steel or aluminum cans, rubber gaskets, and Teflon covers. 
Table 2. Materials List

\author{
Electrode \\ activated carbon \\ activated carbon fibers \\ carbon foam \\ metal additive \\ nickel \\ aluminum
}

Electrolyte: Aqueous

potassium hydroxide

sulfuric acid

$(\mathrm{KOH})$

$\left(\mathrm{H}_{2} \mathrm{SO}_{4}\right)$

Electrolyte: Organic Liquids

propylene carbonate

dimethoxyethane

dimethyl carbonate

diethyl carbonate

(DME)

(DEC)

Electrolyte: Organic Salts

tetra-alkyl ammonium

trifluoromethanesulfonate (Triflate)

trifluoromethanesulfonimide (TFSI)

(trifluoromethanesulfonyl) methide (Methide)

hexafluorophosphate $\left(\mathrm{PF}_{6}\right)$

tetrafluoroborate $\left(\mathrm{BF}_{4}\right)$

\section{Other Materials}

\begin{tabular}{|c|c|}
\hline Separator & $\begin{array}{l}\text { polypropylene } \\
\text { polyethylene } \\
\text { nylon } \\
\text { cellulosics } \\
\text { glass fibers }\end{array}$ \\
\hline Cell cover & Teflon \\
\hline Current collector & $\begin{array}{l}\text { graphite } \\
\text { copper } \\
\text { aluminum } \\
\text { nickel } \\
\text { plastic with carbon black fill }\end{array}$ \\
\hline Gaskets & rubber \\
\hline Capacitor Can & $\begin{array}{l}\text { stainless steel } \\
\text { rolled steel } \\
\text { aluminum } \\
\text { nickel }\end{array}$ \\
\hline
\end{tabular}




\section{Health and Safety Issues}

Health and safety issues regarding electrochemical capacitors are important in the commercialization process. These issues can arise during manufacturing, capacitor use in vehicles, or disposal. The manufacturing and disposal stages of capacitor life present the most issues. The Occupational Safety and Health Administration (OSHA) is the primary regulatory agency for worker exposure during these stages, and OSHA regulations also apply to hazards for research workers. Companies that manufacture or dispose of electrochemical capacitors must comply with OSHA regulations.

Under unusual circumstances, such as serious accidents or device failure, EH\&S issues could be a concern during use of capacitors in vehicles. The National Highway Traffic Safety Administration (NHTSA) is the government agency that regulates these issues, and electrochemical capacitors could be subject to future NHTSA regulations. Vehicle manufacturers and their subcontractors would need to mitigate electrochemical capacitor hazards during vehicle use to comply with such regulations.

This chapter will consider the safety status of electrochemical capacitors, the intrinsic possible hazards of capacitor materials, and mitigation to reduce the risks of these hazards. The focus is on facilitating the resolution of issues that might arise for developers of this technology. Certain hazards are intrinsic to materials that may be used in electrochemical capacitors. Although some hazards exist, mitigation of the intrinsic materials hazards through engineering design and workplace practices can reduce the risks associated with electrochemical capacitors.

This discussion of health and safety issues does not imply that there will be "problems" or unmitigated hazards with commercial electrochemical capacitors, nor does it compare the hazards of electrochemical capacitors to those of other energy storage systems. Instead, it describes the intrinsic material hazards and some methods to mitigate those hazards. Although a comprehensive life-cycle hazard analysis is not provided here, some of the hazards described in this section relate to manufacturing of materials that may be used in electrochemical capacitors, such as carbon fibers or foams. Because these precursor materials are inputs to many other manufacturing processes besides manufacturing of electrochemical capacitors, addressing the hazards associated with their use is not solely an electrochemical capacitor issue.

\section{Safety Status}

Electrochemical capacitors for advanced vehicles are not yet commercially available, and results of safety testing of capacitors for vehicle applications were not publicly available as of May 1996. Safety testing of electrochemical capacitors for advanced vehicles will be an important part of the commercialization process. Electrochemical capacitors for advanced vehicles may need safety tests similar to those used for traction batteries in vehicles, such as the Society of Automotive Engineers' "Recommended Practice for Electric and Hybrid Electric Vehicle Battery Systems Crash Integrity Testing" (1996). This section will describe the safety status of other commercial devices and prototype devices. 
Possible safety incidents during use of electrochemical capacitors include electrical shock, chemical leakage, and fire or explosions. In a properly functioning device, safety incidents should not occur. The following paragraphs examine the electrical and mechanical hazards that must be mitigated to prevent safety incidents, followed by an examination of the intrinsic material hazards that would become relevant for a disassembled device during manufacturing, disposal, or possible leakage of a device.

Sandia National Laboratories conducted an evaluation of electrochemical capacitors for a military application. One of the tests was an aging test, which did not reveal safety hazards. Other tests included vibration and high g-force shock, which will be discussed in the Mechanical Hazards section (Clark and Baca 1993).

\section{Electrical Hazards}

Electrochemical capacitors would pose shock hazards similar to those of batteries. Electrochemical capacitors are designed to deliver high power, and high-power devices pose electrical hazards. Evaluation of shock hazards in advanced vehicles has been the subject of close scrutiny, for example, by the Electric Power Research Institute (EPRI 1995).

Hazards posed by electrical abuse or malfunction of electrochemical capacitors include hazards of overvoltage and short circuit.

Overvoltage has caused decomposition of electrolytes to produce flammable gases in abusive tests of electrochemical capacitors. When gas forms, internal pressure builds up. If electrolyte decomposition causes enough pressure, the container will swell and rupture. This type of event generally causes open-circuit failure. In small electrochemical capacitors, the pressures and quantities of gas involved are small enough to raise few concerns about the hazards of these events. In electrochemical capacitors for advanced vehicles, larger quantities of flammable gases may be released, and the rupture of cells within the vehicle may be a greater concern. Venting could pose a fire hazard if sparks or sufficient heat were near enough to ignite the gas.

Appropriate electrical control, thermal management, and good cell balance can reduce the occurrence of overvoltage. Capacitor container design and placement of the device within the vehicle can reduce the risks associated with these hazards.

Short circuit and rapid discharge of electrochemical capacitors is a second type of electrical hazard. Electrical arcing and associated fire hazards can occur during short circuit. This hazard and its mitigation are similar to those of short circuits in batteries, which are discussed elsewhere in the literature (e.g., EPRI 1995). 


\section{Mechanical Hazards}

Mechanical abuse of electrochemical capacitors, such as crushing or penetration with a metal spike, can cause short circuits, described above. Electrolyte spills during these types of abuse tests would vary in magnitude, depending on the amount of free electrolyte. In designs containing little or no free electrolyte, spills are likely to be small or nonexistent.

Sandia National Laboratories conducted vibration and high-g shock tests on electrochemical capacitors. Although performance of single cells was not affected by the vibration test, performance of assemblies of the tested prototype cells was reduced (Clark and Baca 1993). An improved cell design eliminated this problem, which was apparently caused by a faulty adhesive (Clark 1996).

The high-g shock tests found momentary voltage loss, but no hazard was associated with this test (Clark and Baca 1993). In advanced vehicles, high-g shock could occur, so additional high-g shock tests on actual devices for that application will be needed to verify that no hazardous conditions occur.

\section{Intrinsic Material Hazards}

Materials that may be used in electrochemical capacitors have certain intrinsic hazards. Understanding these hazards aids in reducing the associated risks. Intrinsic material hazards could pose occupational hazards during manufacturing, recycling, or reclamation, or could arise as hazards during normal vehicle use or vehicle accidents. This section will present intrinsic material hazards of electrodes, electrolytes, and other materials that may be used in electrochemical capacitors. Information on how to mitigate these hazards during vehicle use, in vehicle accidents, and in manufacturing will also be presented.

Four types of standards for occupational exposure are presented here: Permissible Exposure Limits (PELs), Short Term Exposure Limits (STELs), Threshold Limit Values (TLVs), and Biological Exposure Indices (BEIs). When material hazards occur in the workplace, the OSHA may regulate the allowable worker exposure, as described in the Code of Federal Regulations, Title 29 (29 CFR). PELs establish two types of exposure limits: time-weighted average (TWA) amounts of airborne exposure permitted during any 8-hour shift of a 40-hour work week, and STELs for TWA amounts of airborne exposure permitted during a 15-minute time period. The TWAs and STELs are indicated in Table 3 if an exposure limit has been established for the material. Once they are promulgated, the OSHA PELs listed in the table will become enforceable.

The American Conference of Governmental and Industrial Hygienists (ACGIH) establishes TLVs and BEIs to guide industrial hygiene practices. TLVs and BEIs, like PELs, apply to 8-hour shifts of a 40hour work week, but do not have the force of regulation. TLVs establish TWA amounts of airborne exposure, whereas BEIs indicate the permissible levels of chemicals in biological specimens, such as urine and blood. 
Table 3. Occupational Standards

\begin{tabular}{|c|c|c|c|}
\hline \multirow[t]{2}{*}{ Substance } & \multicolumn{2}{|c|}{ Standards } & \multirow[t]{2}{*}{ Source } \\
\hline & TWA & STEL & \\
\hline Aluminum (metal dust) & $10 \mathrm{mg} / \mathrm{m}^{3}$ & & 1 \\
\hline $\begin{array}{l}\text { Aluminum (pyro powders and } \\
\text { welding fumes; as Al) }\end{array}$ & $5 \mathrm{mg} / \mathrm{m}^{3}$ & & 1 \\
\hline $\begin{array}{l}\text { Aluminum (metal, respirable } \\
\text { fraction; as Al) }\end{array}$ & $5 \mathrm{mg} / \mathrm{m}^{3}$ & & 2 \\
\hline Aluminum (metal, total dust; as $\mathrm{Al}$ ) & $15 \mathrm{mg} / \mathrm{m}^{3}$ & & 2 \\
\hline Copper (fume) & $0.2 \mathrm{mg} / \mathrm{m}^{3}$ & & 1 \\
\hline Copper (fume) & $0.1 \mathrm{mg} / \mathrm{m}^{3}$ & & 2 \\
\hline Copper (dusts and mists; as Cu) & $1 \mathrm{mg} / \mathrm{m}^{3}$ & & 1,2 \\
\hline Formaldehyde & & $0.3 \mathrm{ppm}$ & 1 \\
\hline Formaldehyde & $0.75 \mathrm{ppm}$ & & 2 \\
\hline $\begin{array}{l}\text { Graphite (all forms except graphite } \\
\text { fibers; respirable fraction) }\end{array}$ & $2 \mathrm{mg} / \mathrm{m}^{3}$ & & 1 \\
\hline $\begin{array}{l}\text { Graphite, synthetic (respirable } \\
\text { fraction) }\end{array}$ & $5 \mathrm{mg} / \mathrm{m}^{3}$ & & 2 \\
\hline Graphite, synthetic (total dust) & $15 \mathrm{mg} / \mathrm{m}^{3}$ & & 2 \\
\hline Graphite, natural (respirable dust) & $\begin{array}{c}15 \times 10^{6} \\
\text { particles/ft }{ }^{3}\end{array}$ & & 2 \\
\hline $\begin{array}{l}\text { Nickel (metal and insoluble } \\
\text { compounds; as Ni) }\end{array}$ & $1 \mathrm{mg} / \mathrm{m}^{3 *}$ & & 1,2 \\
\hline Potassium hydroxide & & $2 \mathrm{mg} / \mathrm{m}^{3}$ & 1 \\
\hline Resorcinol & $45 \mathrm{mg} / \mathrm{m}^{3}$ & & 1 \\
\hline Sulfuric Acid & $1 \mathrm{mg} / \mathrm{m}^{3}$ & & 1,2 \\
\hline Sulfuric Acid & & $3 \mathrm{mg} / \mathrm{m}^{3}$ & 1 \\
\hline $\begin{array}{l}\text { * Notice of Intent to Change } \\
\text { Standard to: } \\
0.05 \mathrm{mg} / \mathrm{m}^{3} \text { (ACGIH) }\end{array}$ & & & $\begin{array}{l}\text { 1. ACGIH 1995-1996 } \\
\text { 2. } 29 \text { Code of Federal } \\
\text { Regulations } 1910 \text { (OSHA 1995) }\end{array}$ \\
\hline
\end{tabular}


In addition to the occupational exposure standards, information about the United States Environmental Protection Agency's (EPA) listings of hazardous chemicals will be provided if materials are included on these lists.

\section{Electrodes}

Human exposure to hazards of carbon-based electrode materials is most likely to occur during electrochemical capacitor production or recycling. Four types of electrode materials could pose hazards in these occupational settings: carbon dust, metals, carbon fibers, and carbon foam.

\section{Carbon Dust}

Carbon is subject to occupational standards in the form of a PEL and a TLV for graphite dusts (ACGIH 1995; OSHA 1995). Activated carbon is a fire and explosion hazard, when the dust is exposed to heat or flame. Freshly activated carbon may heat spontaneously as it reacts with air and water (HSDB 1996). The very small particle sizes that are used in electrochemical capacitors provide a large surface area. This presents two possible problems. First, the small particle size means that the particles could be inhaled deep into the lungs. Second, the large surface area presents the possibility of dangerous chemical reactions, such as rapid oxidation.

The amount of carbon dust generated depends on manufacturing or recycling procedures and exposure control measures.

\section{Metals}

Metal fibers or matrices have been used to decrease the resistance of the electrode, including nickel fibers and aluminum in a matrix (Farahmandi et al. 1994; Farahmandi and Blank 1994). Metal dusts, including nickel and alurninum dusts, can pose fire and explosion hazards. Exposure to nickel or aluminum during capacitor manufacturing could occur, but the extent of exposure would depend on production or recycling procedures and exposure control measures. Because these metals have PELs and TLVs, manufacturers are required to mitigate the hazards of these metals in the workplace. Exposure from the device itself is unlikely, unless destructive processes during accidents generated metal dust or combustion products.

Nickel. Nickel has a PEL and a TLV (ACGIH 1995; OSHA 1995). The ACGIH has issued a notice of intent to change the TLV for nickel to a more stringent level, and to reclassify it as a confirmed human carcinogen (ACGIH 1995). The National Institute for Occupational Safety and Health has reconmended that the PEL for nickel compounds be reduced to $0.015 \mathrm{mg} / \mathrm{m}^{3}$, based on evidence of carcinogenicity of inhaled nickel compounds (ACGIH 1991). 
In addition to carcinogenicity, this TLV was established because nickel damages the lungs of experimental animals. Skin sensitivity among workers exposed to nickel is also a concern, but the TLV may not provide protection from this health effect. In humans, acute toxicity is rare (Patty's 1981).

Nickel powder reacts with air, strong acids, and oxidants. It is flammable, and can release toxic gases upon combustion (HSDB 1996).

Aluminum. Aluminum metal also has a PEL and a TLV (ACGIH 1995; OSHA 1995). The insoluble forms of aluminum produce no measurable acute response (Patty's 1986). Acute aluminum toxicity in humans is unlikely (HSDB 1996). Although it is not acutely toxic, its health effects include impacts on the gastrointestinal tract, the lungs, and various systemic effects, such as neurological disease. Aluminum also affects the intestines. Inhalation of aluminum dust may contribute to pulmonary fibrosis and emphysema. And finally, aluminum dust may irritate the eyes and skin, and skin hypersensitivity is possible (HSDB 1996).

\section{Carbon Fibers}

Activated carbon fibers can be prepared from rayon, polyacrylonitrile, pitch, phenolics, or cellulose (Baker 1991; Horovitz 1995). Carbon fibers are used in many other manufacturing processes, not just electrochemical capacitors. Therefore, occupational health and safety issues posed by all of the carbon fiber preparation processes will not be examined in detail.

Polyacrylonitrile (PAN) is by far the most common precursor used to make activated carbon fibers. When PAN is heated to form carbon fibers, decomposition gases include water, ammonia, hydrogen cyanide, carbon monoxide, carbon dioxide, hydrogen, nitrogen, various nitrile gases, and tars (Baker 1991). In addition to direct health impacts from these gases, the oxidation phase of some PAN processing methods has possible thermal runaway and hydrogen cyanide explosion hazards (Thorne 1985). Health and safety implications of these decomposition gases would be important in the preparation of carbon fibers from PAN.

The Federal Fabrics and Fibers, Inc., preparation process produces carbon dioxide and carbon monoxide. Carbon monoxide is controlled using a catalytic converter (Horovitz 1996).

The carbon fibers themselves pose hazards from inhalation of dust, skin irritation, and electrical short circuits. A PEL and a TLV have been established for graphite fibers. Inhalation of carbon fiber dust is irritating, but the carbon fibers are too coarse to damage the lungs the way asbestos and similar fine fibers do. Skin irritation, such as itching and rashes, can occur when carbon fibers become embedded in the skin. Carbon fibers can short out electrical equipment because they are conductive and because air currents can carry them into electrical equipment (Baker 1991). 


\section{Carbon Foam}

The carbon foam technology considered in this report is prepared from resorcinol and formaldehyde (Pekala 1989). Exposure to these compounds could occur during the manufacturing process. Acetone and carbon dioxide may also be used to prepare carbon foam. In addition, hazardous pyrolysis products may be formed during carbonization of the carbon foam electrode.

Formaldehyde. Formaldehyde has a PEL and a STEL (ACGIH 1995; OSHA 1995). It is a confirmed animal carcinogen and suspected human carcinogen. It is listed in the EPA Genetic Toxicology Program, and is subject to EPA Toxic Substances Control Act (TSCA) Inventory reporting. Experimental evidence indicates that formaldehyde is carcinogenic, tumorigenic, teratogenic, and poisonous by various routes of exposure. In humans, it is poisonous by ingestion, causes systemic effects by inhalation, and irritates the skin and eyes (Lewis 1992).

Resorcinol. Resorcinol has a TLV (ACGIH 1995). There is inconclusive experimental evidence of carcinogenicity. It is listed in the EPA Genetic Toxicology Program because of human mutation data. It is subject to EPA TSCA Inventory reporting. Resorcinol is a human poison by ingestion, and is moderately toxic in experimental settings by skin contact and intravenous exposure. It is a skin irritant and a severe eye irritant. Systemic poisoning of the blood and nerves can occur, in the form of a variety of serious disorders. Resorcinol is combustible and can react with oxidants (Lewis 1992).

\section{Electrolytes}

The electrochemical capacitors considered in this report use nonaqueous or aqueous electrolytes. Either of these types of electrolytes can undergo electrolysis if cell voltage outside the electrochemical stability window of the electrolyte occurs. Electrolysis produces gases in both cases: water electrolyzes to hydrogen gas and oxygen gas, and propylene carbonate to propylene gas. Electrolysis of the electrolyte poses hazards from the flammable gases produced and from the internal pressure increase that the gases cause within the cell.

\section{Aqueous Electrolytes}

Various concentrations of sulfuric acid and potassium hydroxide in aqueous solution could be used in electrochemical capacitors. The risks of the hazards posed would be greater for higher concentrations of sulfuric acid or potassium hydroxide.

Sulfuric Acid. Sulfuric acid has a PEL and a TLV. It is reported in the EPA TSCA Inventory as a strong acid that causes severe chemical burns through inhalation, skin contact, or ingestion. Chronic skin exposure can cause dermatitis; chronic inhalation can cause respiratory tract inflammation and chronic bronchitis. 
Sulfuric acid is reactive with a wide variety of materials. Some of these reactions may result in fire or explosion. Its reaction with water can produce heat. Its decomposition products include toxic fumes of sulfur oxides (Lewis 1992).

Potassium Hydroxide. Potassium hydroxide has a STEL. It is reported in the EPA TSCA Inventory. It is a strong base, and is very corrosive to eyes, skin, and mucous membranes. Potassium hydroxide is reactive with a wide variety of materials. Fire or explosion can result from some reactions of potassium hydroxide. It can react violently with water, producing heat. Decomposition products include toxic potassium oxide (Lewis 1992).

\section{Nonaqueous Electrolytes}

Nonaqueous electrochemical capacitor electrolytes contain a salt dissolved in one or more organic liquids.

Organic Liquids. The organic liquids that may be used in electrochemical capacitors are volatile. In poorly ventilated conditions, vapors from these liquids may reach dangerous concentrations, such that the gas displaces too much air. If an exposed individual receives insufficient oxygen, unconsciousness or death may result. Similarly, decomposing or burning any electrolyte organic liquid may produce asphyxiants (carbon dioxide and carbon monoxide).

Propylene Carbonate. Propylene carbonate is mildly toxic when ingested and irritates eyes and skin, in tests on laboratory animals. It is a skin irritant to humans ( $100 \mathrm{mg} /$ day intermittent exposure). It is stable, but will react with oxidizing agents, acids, and bases, especially when heated. Thermal decomposition produces irritating fumes (Lewis 1992). Propylene carbonate may react with water, and will slowly oxidize in air (J.T. Baker Inc. 1994a).

Diethyl Carbonate. Inhaling DEC may cause nausea, vomiting, or headache. Skin and eye contact may cause irritation. Diethyl carbonate is highly flammable. When heated, its decomposition products include acrid smoke and fumes (Lewis 1992). It will react with strong oxidizing agents (J.T. Baker Inc. 1994b).

Dimethyl Carbonate. Inhaling DMC may cause weakness, nausea, or respiratory problems. It irritates the eyes and skin (PPG Industries, Inc. 1994). Acute effects include kidney disorders. It is a highly flammable liquid, and reacts with oxidizing and reducing agents, strong acids and bases, and moist air or water (Sigma-Aldrich). It decomposes when heated, releasing carbon dioxide and methanol (PPG Industries, Inc. 1994).

Dimethoxyethane. Dimethoxyethane is hazardous to fetal development. Its chronic effects include liver, kidney, blood, central nervous system, and reproductive disorders. Acute effects caused by inhaling, ingesting, or skin contact include irritation. It is very flammable, and may react with oxidizing agents and strong acids (Sigma-Aldrich 1992). Light, heat, and air may cause hazardous reactions (Lewis 1992). 
Salts. Tetra-alkyl arnmonium salts are likely salts for the nonaqueous electrolyte. Likely anions are hexafluorophosphate and tetrafluoroborate. Triflate, imide, and methide anions are also possible, but will not be considered here because they appear to be less likely material choices at this time.

Hexafluorophosphate and tetrafluoroborate are fluorides, a group of compounds which has a PEL and a TLV because they are toxic and irritating (ACGIH 1995; OSHA 1995). Chronic exposure to fluorides can cause bone damage, hypertension, and kidney damage (ACGIH 1991). Acute effects of hexafluorophosphate include corrosion and ulceration of the mucous membranes, gastric pain, circulatory shock, and lesions of the heart and liver (HSDB 1996).

Information about tetra-alkyl ammonium salts was obtained from Material Safety Data Sheets (MSDSs) from Aldrich (1996a-f), Sigma Chemical Company(1996a-b), and Johnson Matthey (1991ab, 1985a-b). Hazardous combustion or decomposition products of the tetra-alkyl ammonium salts include carbon monoxide, carbon dioxide, nitrogen oxides, hydrogen fluoride, and ammonium; for the borates, boron oxides; and for the phosphates, phosphorous oxides and phosphine. In salts that include sulfur, sulfur oxides are possible products.

Tetra-alkyl ammonium salts are harmful when inhaled, ingested, or absorbed through the skin. They are initating to the eyes, skin, mucous membranes, and respiratory system. MSDS descriptions of tetraethylammonium hexafluorophosphate and tetrabutylammonium hexafluorophosphate describe the impact on eyes, skin, mucous membranes, and respiratory system as "extremely destructive," and indicate that inhalation may be fatal due to respiratory system impacts (Aldrich 1996; Johnson Matthey 1991a).

Reactions may occur between tetra-alkyl ammonium salts and strong oxidizing agents, acids, and water.

\section{Other Materials}

\section{Polypropylene}

Polypropylene, when free from residual precursors, is inert. Polypropylene decomposes to irritating fumes when heated (HSDB 1996).

\section{Teflon}

Teflon (polytetrafluoroethylene) is inert under ordinary circumstances, although exposure to Teflon precursors or decomposition products can cause polymer fume fever. Polymer fume fever is an influenza-like syndrome. Pulmonary edema has been reported, especially upon exposure to fumes when Teflon is heated to temperatures of $300-500^{\circ} \mathrm{C}$. Some Teflon decomposition products irritate the eyes and mucous membranes. Teflon decomposition products are toxic in experimental animals (HSDB 1996). Exposure to Teflon may raise fluoride levels, posing hazards of fluorides (presented above in the Salts section). International Agency for Research on Cancer has found that there is 
inadequate evidence of carcinogenicity in experimental animals, and no data are available for humans (HSDB 1996).

\section{Copper}

Occupational exposure to copper is subject to a PEL and TLV (ACGIH 1995; OSHA 1995). Ingestion, inhalation, and skin exposure to copper adversely impact human health. Ingestion of copper salts, and, to a lesser extent, of copper, causes gastrointestinal irritation, including vomiting, nausea, and diarrhea (HSDB 1996 ).

Inhalation of copper fumes causes irritation of the respiratory tract and "metal fume fever." Metal fume fever is an influenza-like syndrome with symptoms that disappear after 24 hours. Ulceration and perforation of the nasal septum may occur (HSDB 1996)

Skin exposure to copper dust may result in severe irritation and discoloration of the skin. Itching and inflammation of the skin occurs in some individuals exposed to copper metal. Allergic contact dermatitis has been observed in individuals following a patch test using a copper penny or copper sulfate solution. There are no human data and inadequate animal data from assays with copper compounds to test its carcinogenicity (HSDB 1996). Copper can react with chlorine, fluorine, sulfuric acid, and potassium dioxide (Lewis 1992).

\section{Rubber}

Rubber is a flammable solid. Combustion or decomposition products can be irritating to eyes and lungs.

\section{Steel}

Stainless steel contains nickel, the hazards of which are indicated above. However, nickel contained in steel does not pose health hazards unless it becomes separated from the steel in a form that could be inhaled, absorbed, or ingested.

\section{Mitigation of Intrinsic Material Hazards}

Intrinsic hazards of electrochemical capacitor materials can be mitigated through design features and workplace procedures. Design features primarily mitigate exposure to intrinsic material hazards during vehicle use or vehicle accidents; workplace procedures reduce risks during manufacturing and recycling processes.

\section{Design Features}

The design of electrochemical capacitors can mitigate the intrinsic hazards of their materials through appropriate thermal management, electrical system design, containment, and venting. 


\section{Thermal Management}

A thermal management system should prevent thermal hazards, such as electrical imbalances that could lead to local heating, during vehicle use. Electrochemical capacitors produce heat during operation. Improving the efficiency of capacitors, so that they produce little heat, is an ongoing development goal. However, thermal management is likely to remain a concern, even in highefficiency devices. Scaling up prototypes to larger commercial devices requires consideration of the thermal impacts of the larger size. Heat from other vehicle components could also raise the temperature of the device.

Thermal management is important to protect capacitor materials from high temperatures and to prevent uneven heating. Operating temperature ranges for commercial capacitors with an aqueous electrolyte can be on the order of $-40^{\circ} \mathrm{C}$ to $+85^{\circ} \mathrm{C}$ (NEC Corp. 1995). For organic electrolytes, operating temperature ranges vary depending on the exact composition of the electrolyte, and are approximately $-20^{\circ} \mathrm{C}$ to $+80^{\circ} \mathrm{C}$ (Murphy 1997). Uneven heating could cause electrical imbalances within a capacitor stack, leading to local overvoltage with the associated possibility of electrolyte electrolysis (see "Electrical System" below).

To ensure uniform temperature and adequate cooling, thermal management considerations may require limits on the size of a capacitor stack, an appropriate location for the capacitor within the vehicle, and air cooling. Minimizing damaging or dangerous voltage imbalances from localized heating can be accomplished by narrowing the voltage operating window so that no single cell will exceed design targets for the voltage range. These design issues would be addressed for performance, but would also improve safety.

\section{Electrical System}

The electrical system design is another hazard mitigation approach that primarily reduces risks of electrolyte decomposition during vehicle use. Protecting electrochemical capacitors from voltages outside the electrochemical stability window of the electrolyte prevents its decomposition. This type of protection is essential for maintaining capacitor performance, so design for performance is likely to mitigate hazards posed by electrolyte electrolysis.

\section{Containment}

Capacitor containment reduces risks during vehicle use and vehicle accidents by mitigating hazards of material spills and internal pressure. These electrochemical capacitors use liquid electrolyte, which theoretically could leak if containment failed. However, many capacitor designs contain little or no free liquid. In such capacitor designs, hazards of spills would be minimal. Minimizing the amount of electrolyte used limits the risks of spills. In addition, the design of the container and seals could help prevent containment failure. The container may need to be strong enough to withstand internal expansion and pressure buildup, if necessary. 


\section{Venting}

Venting might be needed either during normal vehicle use or during a vehicle accident. The normal operation of electrochemical capacitors may generate carbon dioxide gas, if the carbon electrode is oxidized. Some electrochemical capacitors with sulfuric acid electrolytes are designed to include a carbon dioxide-selective valve that permits carbon dioxide release without drying of the electrolyte (Evans 1991). If devices for advanced vehicles produce carbon dioxide gas, venting may be needed.

In contrast to the slow release of carbon dioxide, more rapid electrolyte decomposition to gases occurs during electrical abuse, such as overvoltage. This process is described in the Intrinsic Material Hazards section. Gas buildup could raise internal pressure, causing containment failure. Under high internal pressure conditions, containers of existing devices fail at weak points such as valves and seals. In designing electrochemical capacitors for advanced vehicles, containment failure under high internal pressure conditions should be understood.

\section{Workplace Design and Procedures}

Workplace design and procedures can mitigate intrinsic material hazards in occupational settings. OSHA requires that employers mitigate the hazards of materials for which a PEL or a STEL have been established. Possible electrochemical capacitor materials with exposure limits include aluminum, copper, formaldehyde, graphite, nickel, potassium hydroxide, and sulfuric acid. Other materials used or byproducts formed during manufacturing or recycling could also be hazardous, such as pyrolysis products of carbonization processes. Worker protection procedures can control worker exposure to dust, fumes, and liquids to limit inhalation, ingestion, and skin exposure.

Protective measures include containment of hazardous materials, emergency equipment, ventilation and respiratory protection, and protective clothing. These measures will be described here, but specific protective measures would need to be selected based on the hazard or combination of hazards posed by actual workplace conditions. Containment of hazardous materials may be accomplished by arranging processes so that materials are always in some type of container, by keeping containers closed, by storing and handling materials in spaces designed to prevent leaks and spills, and by instituting good housekeeping and personal hygiene practices such as sweeping and hand washing.

Emergency equipment may include fire extinguishers and extinguishing systems and safety showers and eye washes. Ventilation and respiratory protection measures include fume hoods, general building ventilation systems, gas masks, and self-contained breathing systems. Protective clothing includes a change of clothes for work, lab coats and aprons, gloves, chemical suits, boots, and safety glasses or goggles. 


\section{Conclusions}

A variety of intrinsic material hazards are associated with possible materials for electrochemical capacitors, primarily during manufacturing or recycling. Electrode materials that pose hazards include carbon dust, metals, carbon fiber by-products, and carbon foam precursors. Both aqueous and nonaqueous electrolytes can be hazardous. Aqueous electrolytes can cause severe chemical burns because they are strong acids and bases. Nonaqueous electrolytes contain organic liquids and salts that can pose toxicity hazards such as irritation and chronic toxicity, and safety hazards such as flammability.

Mitigation of intrinsic materials hazards through engineering design and workplace practices is possible. Hazard mitigation reduces the risks associated with the devices. Safety tests of electrical and mechanical performance have found that abuse conditions can cause safety hazards, and mitigation to prevent these electrical abuses and ensure mechanical integrity will enhance the safety of commercial electrochemical capacitors for advanced vehicles. In addition, evaluating the possibility of containment failure under high internal-pressure conditions may be part of safety testing. 


\section{Environmental Issues}

Environmental regulations and waste minimization are important considerations in developing new energy storage technologies. This chapter presents an overview of some environmental regulations and waste minimization issues that may affect electrochemical capacitors. An assessment of the environmental effects of the entire electrochemical capacitor life cycle is not attempted here. Such an assessment, especially in comparison to a similar assessment of competing energy storage devices, would aid the evaluation of electrochemical capacitors for advanced vehicles.

\section{Environmental Regulation}

Electrochemical capacitor manufacturing processes may generate wastes that could be discharged to water, air, or landfills. Environmental regulation of these effluents occurs at the federal, state, and local levels. Some of the applicable federal regulations will be considered here. The U.S. Environmental Protection Agency is the federal government entity responsible for regulating environmental discharges. Three acts of Congress provide the legislative basis for EPA's regulation of these effluents: the Clean Water Act (CWA), the Clean Air Act (CAA), and the Resource Conservation and Recovery Act (RCRA). These acts and their impacts on electrochemical capacitor industries are summarized below.

\section{Clean Water Act}

The CWA authorizes a regulatory program to control industrial discharges. The National Pollutant Discharge Elimination System (NPDES) permitting process is the primary regulatory approach. The CWA establishes industrial effluent standards, water quality standards, and storm water discharge restrictions that are used in the permitting program.

The NPDES requires that facilities obtain permits for direct discharges of pollutants and to storm water runoff "navigable waters." "Navigable waters" include virtually all waters except impoundments.

Industrial effluent standards apply to three different types of pollutants: toxic pollutants; conventional pollutants such as materials increasing the biological oxygen demand, suspended solids, fecal coliform, and $\mathrm{pH}$; and nonconventional pollutants such as ammonia and chlorine. Industrial facilities are required to reduce these pollutants, usually subject to a "best available technology" standard.

The CWA designated 65 toxic pollutants that are listed in 40 CFR 401.15. Nickel is the only toxic pollutant listed in the CWA that has been identified in this report as a possible electrochemical capacitor material.

The CWA requires states to establish water quality standards, which must conform with federal requirements. If water quality standards are not met, the state may require, in addition to best 
available technology, further reductions in industrial discharges of toxic, conventional, and nonconventional pollutants that impact the body of water where violations occur.

A special set of regulations apply to industrial dischargers to publicly owned treatment works (POTWs). Individual POTWs issue industrial discharge permits to industries discharging to that POTW's system. Publicly owned treatment works are subject to the permit requirement of NPDES. If a POTW can meet its effluent limits, discharges to that POTW from industrial facilities are exempt from NPDES. However, a discharge to a sewage system not connected to an operable treatment works is subject to NPDES (40 CFR 122.3[c]).

Facilities discharging to POTWs are required to comply with the general pretreatment standards and any applicable categorical pretreatment standards (40 CFR 403). General pretreatment standards focus on preventing the discharge of pollutants into POTWs that interfere with their operation, or pass through untreated. Categorical pretreatment standards apply to certain pollutants from certain industries.

General pretreament standards include prohibiting the introduction into POTWs of pollutants that:

- $\quad$ Create a fire or explosion hazard.

- $\quad$ Have a pH of less than 5.0, unless the POTW is designed for such low pH levels. Although the lower $\mathrm{pH}$ limit is established in the regulation, the POTW sets the acceptable upper $\mathrm{pH}$ limit in the effluent it receives.

- $\quad$ Emit toxic gases, vapors, or fumes in quantities that may cause acute health and safety problems.

Some of the possible electrochemical capacitor materials may be subject to general pretreatment standards. For example, sulfuric acid could reduce the $\mathrm{pH}$ below the limit for the POTW, and potassium hydroxide could raise the $\mathrm{pH}$ above the limit. The organic liquids for the electrolyte are flammable. Some materials have toxic gaseous decomposition products. The quantity of acidic, basic, flammable, or toxic material would be an important factor in determining whether pretreatment standards were met.

Categories of industries subject to categorical pretreatment standards include electrical and electronic components, battery manufacturing, ferroalloy manufacturing, nonferrous metals manufacturing, inorganic chemicals, and plastics molding and forming. Industries related to electrochemical capacitor manufacturing and disposal may be included among these.

Storm water discharges are also subject to regulation. Storm water discharge regulations focus on implementing pollution prevention practices. 


\section{Clean Air Act}

The CAA regulates emissions of hazardous air pollutants, emissions from certain categories of manufacturing, and ambient levels of certain air pollutants. All of these regulatory approaches could impact electrochemical capacitor manufacturing or disposal.

The Clean Air Act Amendments of 1990 list 189 substances as hazardous air pollutants (HAPs) (Clean Air Act Amendments section 112[b]) that must be regulated. Any stationary source that emits more than 10 tons per year of one of these pollutants, or 25 tons per year of a combination of these pollutants, is considered a major source.

The EPA published a list of major source categories and subcategories to be regulated under CAA Amendments 112 (Federal Register 1992). The EPA also established a schedule for promulgating emission standards for each listed source category (Federal Register 1993). Electrochemical capacitor manufacturing or disposal is not a listed major source, but production of some of the materials contained in electrochemical capacitors could be affected under listings such as primary and secondary aluminum production, stainless steel manufacturing, acrylonitrile production, production of inorganic chemicals, and production of organic chemicals.

In addition to restricting emissions of hazardous air pollutants, the regulations authorized in the CAA address ambient air pollutants. Each state is responsible for maintaining air quality within its borders in keeping with the national ambient air quality standards. To do so, states may use state operating permit programs (40 CFR 70) to restrict industrial emissions that cause ambient air pollution. Emissions of volatile organic compounds, nitrogen oxides, carbon monoxide, sulfur dioxide, and fine particles from electrochemical capacitor facilities may face such restrictions.

\section{Resource Conservation and Recovery Act}

RCRA is the primary act governing regulation of solid hazardous waste. Disposal of manufacturing wastes or spent electrochemical capacitors would be easiest if this material could be recycled or classified as nonhazardous waste. The total amount of waste generated from electrochemical capacitors in advanced vehicles depends on the success of the technology. If $1 \%$ of the roughly 9 million new cars purchased each year contained a 40-kilogram $(\mathrm{kg})$ device (the Fast Response Engine technical target), 3.60 million $\mathrm{kg}$ of spent capacitors would need to be disposed at the end of device life. The number of devices used during a vehicle's life time could vary, depending on cycle and calendar life of the electrochemical capacitor, and on duty cycle and calendar life of the vehicle. Other waste material would be generated during manufacturing. This section will identify ways in which this waste could be subject to RCRA, and the resulting compliance actions, including waste minimization.

Materials from the manufacturing or disposal of electrochemical capacitors could be subject to RCRA in several ways. Solid wastes are subject to RCRA if they can be categorized as follows: (1) they 
are "listed" wastes, (2) they are "characteristic" wastes, or (3) they are mixed with listed wastes. RCRA places requirements on facilities that generate, transport, treat, store, or dispose of these solid wastes.

Section 1004(27) of RCRA defines solid waste as "any garbage, refuse, sludge from a waste treatment plant, water supply treatment plant or air pollution control facility and other discarded material, including solid, liquid, semisolid, or contained gaseous materials resulting from industrial, commercial, mining and agriculture activities from community activities." Solid or dissolved material in domestic sewage, irrigation retum flows, or industrial surface water is not included in this definition. However, these sources may require a permit under CWA.

Listed wastes can be found in 40 CFR 261, Subpart D. Few electrochemical capacitor materials considered in this report are listed as wastes subject to RCRA. Nickel, which has been used in some devices, is a listed waste. Other listed wastes are used to manufacture electrochemical capacitor materials, such as acetone and acrylonitrile.

In addition to listed wastes, wastes that meet the characteristic waste criteria may also be classified as hazardous. Wastes that are corrosive, flammable, reactive, or toxic are considered characteristically hazardous. For example, among the electrochemical capacitor materials, sulfuric acid, potassium hydroxide, and tetra-alkyl ammonium salts could be corrosive; organic liquids for the electrolyte could be flammable. Corrosiveness is defined by $\mathrm{pH}$ or steel corrosion; flammability is defined by flash point.

To comply with RCRA, manufacturing or disposal companies must first determine what type of hazardous waste, if any, they are generating or disposing. If a waste is a hazardous waste, the appropriate treatment standard must be determined. If the waste meets the treatment standard, then disposal in a landfill is permitted. If the waste does not meet the standard, then the waste must be treated to meet the standard before disposal.

The quantity of waste that a business generates determines the stringency of requirements for such items as manifests, reports, plans, training, and storage.

Hazardous waste generators are required under RCRA to practice waste minimization. The EPA defines "generator" to include any facility, operator, or person who first creates a hazardous waste, or first makes the waste subject to RCRA regulations. Generators must certify that they have a program in place to reduce the volume and toxicity of hazardous wastes as much as economically practicable. They must also select the method of treatment, storage, or disposal that minimizes the threat to human health and the environment (Hall et al. 1993). To expedite recycling, the Universal Waste Rule (40 CFR 273) may exempt generators and handlers of certain hazardous wastes from RCRA hazardous waste handling and storage requirements. 


\section{Waste Minimization}

Waste minimization means reducing hazardous waste by decreasing the total quantity, the toxicity, or both. Methods to accomplish waste minimization include source reduction and recycling or reclamation.

\section{Source Reduction}

Hazardous wastes can be reduced at the source by using products that generate less waste, or by changing the manufacturing process to reduce waste. Products can generate less waste if they have a long useful life, or if parts can be reused. Manufacturing changes that can reduce waste include changes in input material, technology, procedures, and institutions.

\section{Life}

Cycle life and calendar life will determine what quantity of solid waste electrochemical capacitors produce. One of the anticipated advantages of electrochemical capacitors is a cycle life exceeding that of batteries. The actual cycle life of future electrochemical capacitors for advanced vehicles is unknown. The Idaho National Engineering Laboratory has performed tests demonstrating over 100,000 cycles on an 8-cell, 24-V, organic electrolyte prototype system from Maxwell. Aqueous electrolyte devices commercialized for other applications achieve greater than 100,000 cycles (Raistrick 1993). Achieving long cycle life and calendar life at the maximum voltage are important performance goals for technology development, and life will greatly impact the volume of material that electrochemical capacitors will generate for recycling or disposal. Electrochemical capacitors are expected to provide environmental benefits compared to alternative energy storage systems because of their anticipated long cycle life.

\section{Reuse}

Reuse of parts of the electrochemical capacitor may be possible. Capacitor containers are the most likely candidates for reuse. If containers could be easily emptied, adequately cleaned, refilled with active materials, and resealed, then reuse might be an option.

The reuse of electrode materials depends on the ease with which a useful product can be recovered. Easy disassembly (discussed below) can facilitate reuse. Depending on the reason for failure of the cell and on cell design, it might be possible to recondition the electrode materials and introduce new electrolyte to restore cell function.

\section{Manufacturing}

Controlling sources of hazardous wastes during manufacturing is another method to reduce waste. Input material, manufacturing technology, and procedures or institutions can influence the quantity of wastes. 
Changes in input materials to reduce hazardous wastes could include use of purer starting materials, more dilute materials, or substitution of less hazardous materials. Using purer or more dilute inputs would need to be evaluated in the context of a commercial-scale manufacturing process. Substituting less toxic materials may be possible if comparable performance can be achieved. For example, in the choice of an organic liquid for the electrolyte, propylene carbonate has few EH\&S impacts compared to other possible solvents not discussed in this report. It may be possible to select salts and additives that have fewer environmental impacts, without sacrificing performance.

Manufacturing technologies can be selected to limit waste generation. Manufacturing technologies are generally selected to minimize costs subject to regulatory and production constraints. Limiting waste generation can reduce costs by saving valuable materials and reducing disposal and environmental regulatory compliance costs. Considering process, equipment, layout, and operation may reduce waste generation. Specific manufacturing technology measures would need to be designed when electrochemical capacitors were commercialized.

Procedures and institutions also impact waste generation. Keeping hazardous materials from contaminating other materials should be a goal of procedures and institutional practices.

\section{Recycling and Reclamation}

Recycling and reclamation address two opportunities for waste minimization: during manufacturing, and at the end of life of the electrochemical capacitor.

Wastes from manufacturing processes can sometimes be recycled at the production facility. If raw materials can be separated from the waste stream, these can be recycled within the process. Manufacturing processes can be designed to facilitate this alternative. Contamination that is not easily separable and low volume of waste may make recycling during manufacturing economically infeasible.

At the end of useful life, ease of disassembly and recovery of materials will determine the economic feasibility of recycling. Several disassembly scenarios exist for electrochemical capacitors. Electrochemical capacitors could be packaged with a battery. At the end of battery life, the capacitor could be separated from the battery (and reused if it still functioned) or could be sent to a recycling facility with the battery.

If electrochemical capacitors were not packaged with the battery, some devices would fail and need to be removed from the vehicle before the end of the vehicle's life, while other devices would be in the vehicle at the end of its life.

Recycling of electrochemical capacitors could occur at battery recycling facilities, in a separate recycling facility, or, possibly, in vehicle recycling facilities. The steel container of the capacitor would be the most likely material to be recycled. Aluminum used to package cells or as an electrode material might also be recycled, although disassembly could present challenges. Although the organic 
salts are valuable, recovery could be difficult. Recovery of aqueous electrolytes or organic liquids likewise could be difficult, especially in starved electrolyte designs containing little free liquid electrolyte: Acidic and basic aqueous electrolytes might be useful as neutralizing agents.

Existing lead-acid battery recycling facilities might be equipped to recover valuable products from sulfuric acid electrolytes used in some electrochemical capacitors. Lead-acid battery recycling processes can separate out acid, polypropylene, metals, battery paste, and poly vinyl chloride plastic (see Fig. 2). Some processes produce and sell sodium sulfate.

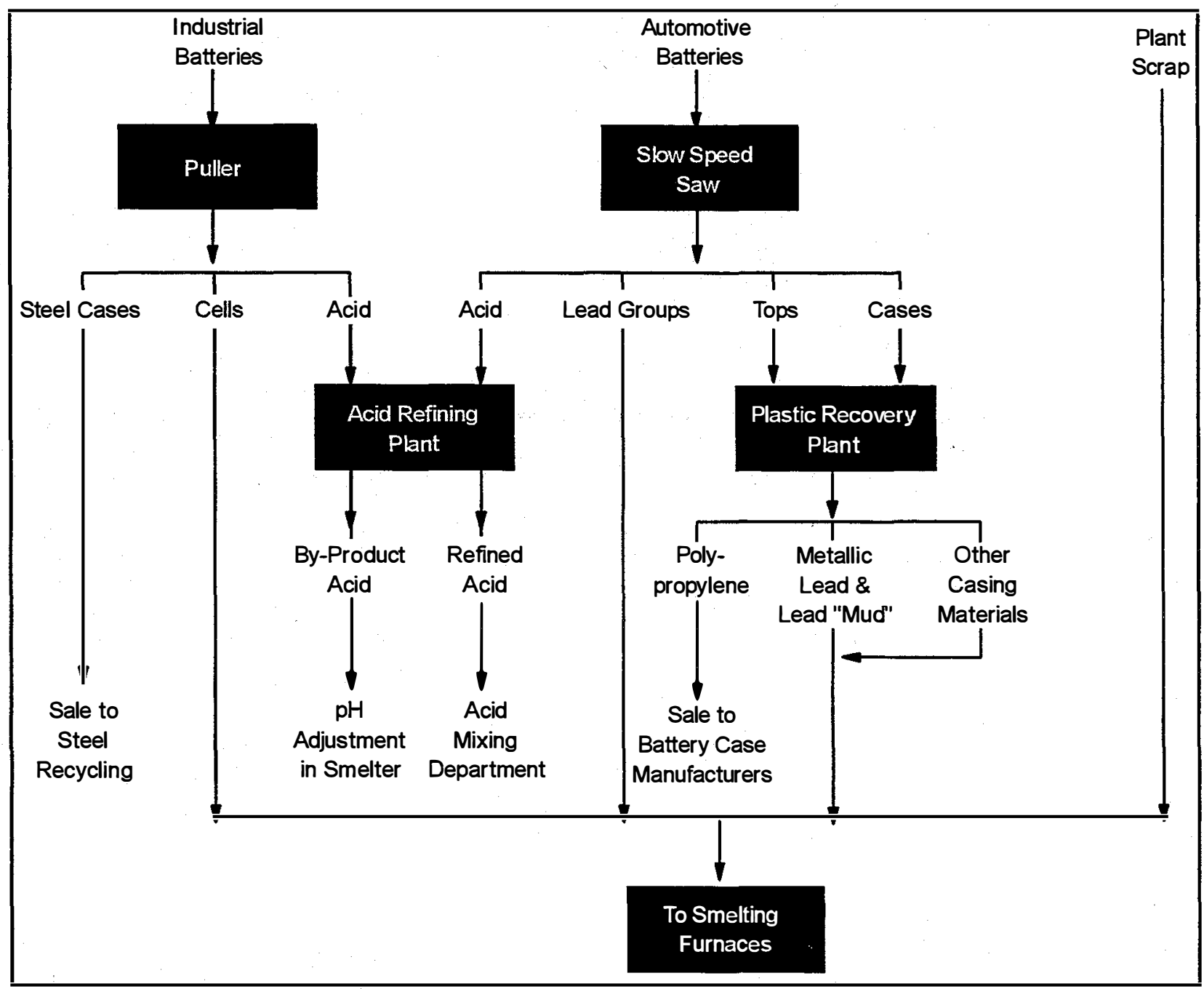

Figure 2. Separation Phase of Lead-acid Battery Recycling Process

Source: Leiby, Bricker, and Spitz 1995 


\section{Conclusions}

The assessment of environmental regulatory status in this report considers current regulations as they might apply to an automotive electrochemical capacitor industry that manufactured the subset of devices considered here. Clean Water Act, CAA, and RCRA-related environmental regulations apply to electrochemical capacitor manufactuning and disposal. Nickel is the only electrochemical capacitor material identified in this report that is a CWA-listed toxic pollutant. Industries needed for electrochemical capacitor manufacturing and disposal may be subject to CWA categorical pretreatment standards. The Clean Air Act does not list electrochemical capacitor manufacturing or disposal as major sources, but production of some of the materials contained in electrochemical capacitors could be affected under other major source listings. Ambient air pollution regulations may also affect electrochemical capacitor manufacturing and disposal. The Resource Conservation and Recovery Act lists some materials that could be used in electrochemical capacitors - as well as materials that could be used in their manufacture - as hazardous wastes. In addition, electrochemical capacitor materials such as sulfuric acid, potassium hydroxide, and tetra-alkyl ammonium salts could be characteristically hazardous wastes.

In general, waste minimization is essential to minimize environmental effects, including those of electrochemical capacitors. Waste minimization reduces the total quantity, the toxicity, or both. Source reduction and recycling or reclamation are alternative methods to accomplish waste minimization. The long cycle life of electrochemical capacitors helps reduce waste at the source. Reuse of capacitor containers is another source reduction possibility. Selecting the least hazardous materials, using efficient manufacturing technologies, and instituting procedures for handling hazardous materials can reduce waste as well. Recycling and reclamation can minimize waste during manufacturing or at the end of life of the electrochemical capacitor. During production, there may be opportunities to separate raw materials from the waste stream for recycling. At the end of useful life, recycling of electrochemical capacitors might occur at battery recycling facilities, in a separate recycling facility, or in vehicle recycling facilities. Steel and aluminum are the most likely materials to be recycled. 


\section{Shipping Requirements}

\section{Introduction}

Electrochemical capacitors may pose hazards in transportation. This chapter examines the regulation of these hazards, including forbidden materials regulations, and regulations that may apply based on electrolyte characteristics. Regulatory and industrial experience mitigating battery hazards in transport may be useful for electrochemical hazards that are similar to battery hazards. Appendix A provides background information on hazardous materials regulations.

As described previously, electrochemical capacitors for HEV power assists are under development. Changes in capacitor materials and design during development may alter the transport hazards of the device. Therefore, this chapter will describe how transport requirements might apply, depending on the materials and design.

\section{Mitigating Hazards of Forbidden Materials and Devices}

Electrochemical capacitors could pose the hazards of forbidden materials, but appropriate design and packaging can mitigate them. Forbidden materials include:

- Electrical devices that may create sparks or generate a dangerous quantity of heat, unless packaged to preclude such an occurrence.

- $\quad$ Packages that emit flammable gas or vapor released from a material not otherwise considered a hazardous material that is likely to create a flammable mixture with air in a transport vehicle. (49 CFR 173.21)

Appendix A includes additional information on U.S. Department of Transportation (DOT) regulation of forbidden materials. Electrochemical capacitors can be transported in a manner that mitigates these hazards. For example, the short circuit of a charged electrochemical capacitor large enough for advanced vehicles could generate heat, but appropriate packaging can prevent short circuits, or capacitors could be shipped in a discharged state. Electrolysis of the electrolyte could release flammable gas, but can be prevented.

\section{Determining Other Transportation Requirements}

To be transported or offered for transport legally, electrochemical capacitors must not violate other applicable requirements of DOT regulations, in addition to the forbidden materials regulation. The person offering an item for transportation must determine whether the item is subject to the regulations and, if so, which requirements apply. The Code of Federal Regulations, Title 49, Chapters 172 and 173 present the procedures and criteria to make this determination. 
To determine whether electrochemical capacitors are subject to DOT regulations, the device must be evaluated according to the Hazardous Materials Criteria of Part 173 (see Appendix A). If the electrochemical capacitor, or any of its materials, poses a hazard, the hazard class must be identified. After all the hazard classes of the electrochemical capacitor and its materials are identified, a table entry can be selected from the Hazardous Materials Table (see Appendix A). The appropriate table entry is the one that best describes the device, and has an associated hazard class that corresponds to the hazards of the capacitor. The table entry indicates which requirements apply. Examples of possible table entries are given below in the "Requirements" section.

\section{Electrolyte Hazards}

The primary electrochemical capacitor characteristic that determines whether the device is considered hazardous and which transportation requirements apply is the composition and quantity of the electrolyte. ${ }^{1}$ The transportation hazards of the materials used in the electrolyte will be presented here.

The electrolyte would either be an aqueous or a nonaqueous electrolyte, as described previously. The nonaqueous electrolyte is an organic liquid with a tetra-alkyl ammonium salt. The aqueous electrolyte is sulfuric acid or potassium hydroxide. Either the aqueous or the nonaqueous electrolyte could be subject to hazardous materials shipping requirements. The manner in which these requirements would apply depends on the exact composition of the electrolyte, which will vary in different designs.

The nonaqueous electrolyte may contain materials that are hazardous in transportation. However, under the DOT regulations, the hazard of the electrolyte depends on its properties, not on the hazards of the individual components of the solution. For example, some of the organic liquids that could be used in the electrolyte meet DOT criteria for flammable liquids. The DOT regulations generally classify liquids with a flash point at or below $60.5^{\circ} \mathrm{C}$ in Class 3, flammable liquids (49 CFR 173.120). ${ }^{2}$ $\mathrm{DEC}$ and DME have flash points below $60.5^{\circ} \mathrm{C}$. The flash point of the electrolyte would depend on the organic liquids, and the proportions of each liquid, used to make the electrolyte. If the flash point of the electrolyte were at or below $60.5^{\circ} \mathrm{C}$, then it would be considered a flammable liquid.

The tetra-alkyl ammonium salt dissolved in the organic liquid may also contribute to the hazards of the solution. These salts may satisfy the definition for classification as a poison, Division 6.1 (40 CFR 173.132). ${ }^{3}$ Depending on the concentration of the salt in the electrolyte, the electrolyte may meet this

${ }^{1}$ Activated carbon is also listed in the Hazardous Materials Table, primarily due to international shipping requirements. The appropriate table entry for activated carbon is Division 4.2, U.N. 1362 .

${ }^{2}$ For transportation by rail or highway, in packages containing 450 liters (119 gallons) or less, a flammable liquid with a flash point at or above $38^{\circ} \mathrm{C}\left(100^{\circ} \mathrm{F}\right)$ need not be considered a hazardous material, unless it is hazardous for some other reason (poisonous, corrosive, environmentally hazardous substance [hazardous substance or waste]) (49 CFR 173.150).

${ }^{3}$ The criteria for classification as a poison are based on toxicity in animal tests. Definitions of criteria for toxicity of liquids consider exposure by three separate routes: oral, dermal, and inhalation of vapors and mists. 
definition. Similarly, corrosiveness of the salt may cause the electrolyte to meet the defining criteria for a corrosive material, Class $8 .^{4}$

Aqueous electrolytes pose hazards as well. Both sulfuric acid and potassium hydroxide meet the criteria for corrosive materials, Class 8 (49 CFR 173.136).

Depending on the characteristics of the electrolyte, various classifications under DOT regulations are possible. It could be considered nonhazardous, or could meet one or more of the definitions for flammable, poisonous, or corrosive liquids, or perhaps other hazard class definitions. The hazards of the electrolyte could affect the transport requirements for the electrochemical capacitor.

\section{Electrolyte Quantity}

In the transport of many batteries, the DOT has determined that, if there is no free electrolyte, the hazard of the electrolyte does not impact the assessment of overall hazards of the battery. Such a battery would be considered "dry." Because electrochemical capacitors and their electrolytes are similar to batteries, this determination may be relevant to electrochemical capacitors. For example, lead-acid batteries are considered dry batteries if electrolytes are in gel form or are contained in the battery separators and electrodes in a starved electrolyte design. Electrochemical capacitors may also have starved electrolyte designs, in which virtually all of the electrolyte resides in the pores of the electrodes or in the separator.

In letters issued by DOT, ${ }^{5}$ a dry battery has been defined as follows:

If ... the batteries are of such a design that no flow of battery fluid would occur if the batteries were ruptured or cracked, and there is no free liquid, we would consider the batteries to be "dry"...

Electrochemical capacitors might also be considered "dry" if they meet these criteria. Then electrolyte hazards would not be considered in determining the overall hazards of the device.

\section{Requirements}

The transportation requirements that would apply to an electrochemical capacitor depend on whether or not the device contains free electrolyte, and, if it contains free electrolyte, on the hazards of the electrolyte. This section presents some of the possible transportation situations and the corresponding hazardous materials table entries.

${ }^{4}$ The determination that a material is corrosive may be based either on its destructiveness to skin in animal tests or on its rate of corrosion to steel or aluminum.

${ }^{5}$ For example, a letter from E.T. Mazzullo of DOT to C.E. Unser of Fire Control Instruments, Inc. (October 31, 1990). 


\section{Dry Electrochemical Capacitor}

If DOT addresses the absence of free electrolyte in electrochemical capacitors the way it has in many batteries, then this case could exist. If there is no free electrolyte, so that the electrochemical capacitor meets the criteria for a dry battery, then the hazards of the electrolyte would not be considered in the overall hazard determination. If no other hazard exists (such as activated carbon), then the electrochemical capacitor would not be considered hazardous and would not be subject to DOT regulations.

\section{Wet Electrochemical Capacitor}

If there is free electrolyte, or if the dry battery approach is not applied by DOT to electrochemical capacitors, then these cases would apply. If electrolyte hazards are the only hazards posed, then the electrolyte hazards determine which regulations apply. If the electrolyte does not meet the definition of any of the hazard classes, then the electrochemical capacitor would not be considered hazardous, and would not be subject to DOT regulations. If the electrolyte meets a definition of a hazard class, likely hazard classes and hazardous materials table entries are listed below. The electrochemical capacitor would be regulated under the hazardous materials table entry most appropriate to the electrolyte.

1. Sulfuric acid and potassium hydroxide electrolytes are classed as corrosive (Class 8) under the following table entries:

Sulfuric acid (with not more than 51\% acid) ${ }^{6}$, Class 8, UN 2796

Potassium hydroxide, solution, Class 8, UN 1814

2. Nonaqueous electrolytes could be classified as flammable (Class 3), poisonous (Division 6.1), or corrosive (Class 8 ), with hazardous materials table entries such as:

Flammable liquids, n.o.s., Class 3, UN 1993

Toxic liquids, organic, n.o.s., Division 6.1, UN 2810

Corrosive liquids, n.o.s., Class $8, \mathrm{UN} 1760^{7}$

Some hazardous materials have combinations of these characteristics. The regulations explain how to classify a material that has more than one hazard (49 CFR 173.2a)

${ }^{6}$ Sulfuric acid concentrations in electrochemical capacitors are unlikely to exceed $51 \%$.

${ }^{7}$ This class is only appropriate if no other, more specific category, such as corrosive acid or base, can apply. 


\section{Packaging of Electrochemical Capacitors}

Some packaging requirements that could apply to DOT-regulated electrochemical capacitors would be impractical for large devices. A regulatory "exemption" issued by DOT could permit alternative packaging to reduce the burden of these requirements. A longer term solution to this problem would be incorporating specific provisions for transporting large electrochemical capacitors into the regulations. For additional details on packaging requirements, see Appendix A.

\section{International Transportation Requirements}

Some electrochemical capacitors might be more easily transported if DOT regulations were changed or clarified, and these capacitors would benefit from corresponding changes to international transportation requirements. Although exemptions can be used domestically, they are generally not a practical approach internationally, because they must be obtained from each country through which a shipment may pass. Therefore, changing the relevant international regulatory standards, if needed, is preferable to obtaining exemptions. Additional information on international transportation requirements may be found in Appendix A.

\section{Conclusions}

A final determination of transport requirements for electrochemical capacitors for advanced vehicles cannot be made yet because these devices are under development and use various designs and materials. Electrochemical capacitors may be subject to varying transport requirements, depending on the design and materials ultimately selected for large commercial devices. The electrolyte characteristics and quantity are important factors in determining which transport requirements would apply. Electrolyte characteristics and quantity may be design elements that electrochemical capacitor manufacturers can modify to reduce the regulatory burdens in transport. 


\section{Summary}

Electrochemical capacitors are a candidate for traction power assists in HEVs. Other advanced automotive applications, while not the primary focus of current development efforts, are also possible. These include load leveling high-energy batteries, power conditioning electronics, electrically heated catalysts, electric power steering, and engine starter power. Higher power and longer cycle life are expected for electrochemical capacitors than for batteries. Evaluation of EH\&S issues of electrochemical capacitors is an essential part of the development and commercialization of electrochemical capacitors for advanced vehicles. This report provides an initial EH\&S assessment.

This report presents electrochemical capacitor electrochemistry, materials selection, intrinsic material hazards, mitigation of those hazards, environmental requirements, pollution control options, and shipping requirements. Most of the information available for this assessment pertains to commercial devices intended for application outside the advanced vehicle market and to experimental or prototype devices. Electrochemical capacitors for power assists in HEVs are not produced commercially now. Therefore, materials for advanced vehicle electrochemical capacitors may change, and so would the corresponding EH\&S issues. Although changes are possible, this report describes issues for likely electrochemical capacitor designs.

Electrochemical capacitor materials have certain health and safety hazards. Engineering design and workplace health and safety measures can mitigate these hazards. Health and safety issues are considered, including safety status, intrinsic material hazards, and mitigation of material hazards. The most significant hazards for normally operating electrochemical capacitors are electrical hazards and hazards from mechanical abuse. They do not expose the user to significant thermal or material hazards. High-voltage hazards of electrochemical capacitors are similar to those of other electrical devices.

Intrinsic material hazards include bone damage from fluoride salts, irritation to eyes and skin from borates, organic salts, and solvents, and irritation to lungs upon inhalation of dusts, such as carbon dust. Nickel, a confirmed human carcinogen, could be used as an electrode additive or current collector. Possible capacitor materials, such as sulfuric acid, would be subject to environmental regulations during recycling or disposal. Shipping requirements will depend on hazards posed by materials, such as the possible fire hazards associated with flammable organic liquids in the electrolyte. To commercialize electrochemical capacitors for advanced vehicles, EH\&S issues such as these will need to be considered.

The design of electrochemical capacitors can mitigate many of the intrinsic material hazards, minimizing the risks associated with these hazards. The design approaches that ensure reliability and durability of electrochemical capacitors will simultaneously mitigate intrinsic material hazards of

materials. For example, design of containment, thermal management, electrical system, and venting can reduce the chance of human exposure to hazards of materials and hazardous electrochemical reactions. Although these design options are expected to reduce risks of electrochemical capacitors, health and safety evaluation of commercial devices for advanced vehicles is needed. 
Wastes produced during manufacturing, recycling, and disposal of electrochemical capacitors are subject to local, state, and federal environmental laws and regulations of air emissions, water effluents, and land disposal. This report describes the parts of CWA, CAA, and RCRA that are likely to apply.

Waste minimization can reduce the environmental impacts and the burden of environmental compliance throughout the life cycle of electrochemical capacitors. Possible recovery and recycling techniques for materials are described, such as recovery of metals and recycling of plastics. The life of the capacitor will determine the volume of spent materials, which impacts the economic viability and environmental significance of recovery and recycling processes. 


\section{References}

ACGIH (American Conference of Governmental and Industrial Hygienists) (1995). Threshold Limit Values (TLVS) for Chemical Substances and Physical Agents and Biological Exposure Indices $(B E I s)$. Cincinnati, OH: American Conference of Govemmental and Industrial Hygienists, Inc.

ACGIH (American Conference of Governmental and Industrial Hygienists) (1991). Documentation of the Threshold Limit Values and Biological Exposure Indices. Sixth Edition, Volumes I-III. Cincinnati, $\mathrm{OH}$ : American Conference of Governmental and Industrial Hygienists, Inc.

Aldrich Chemical Co., Inc. (1996a). Material Safety Data Sheet for Tetrabutylammonium Hexafluorophosphate. Milwaukee, WI: Aldrich Chemical Co., Inc.

Aldrich Chemical Co., Inc. (1996b). Material Safety Data Sheet for Tetrabutylammonium Tetrafluoroborate. Milwaukee, WI: Aldrich Chemical Co., Inc.

Aldrich Chemical Co., Inc. (1996c). Material Safety Data Sheet for Tetrabutylammonium Trifluoromethane-sulfonate. Milwaukee, WI: Aldrich Chemical Co., Inc.

Aldrich Chemical Co., Inc. (1996d). Material Safety Data Sheet for Tetraethylammonium Tetrafluoroborate. Milwaukee, WI: Aldrich Chemical Co., Inc.

Aldrich Chemical Co., Inc. (1996e). Material Safety Data Sheet for Tetramethylammonium Hexafluorophosphate. Milwaukee, WI: Aldrich Chemical Co., Inc.

Aldrich Chemical Co., Inc. (1996f). Material Safety Data Sheet for Tetraethylammonium Tetrafluoroborate. Milwaukee, WI: Aldrich Chemical Co., Inc.

Baker, F.S.; C.E. Miller, A.J. Repik; E.D. Tolles (1991). "Carbon and Graphite Fibers." KirkOthmer Encyclopedia of Chemical Technology, Fourth Edition. New York: John Wiley \& Sons.

Barbee, T. Jr. (1996). Personal communication. Lawrence Livermore National Laboratory, Califomia.

Barnett, B. (1996). Personal communication. A.D. Little, Inc.

Blank, E. (1996). Personal communication. Maxwell Laboratories, Inc.

Clark, N. (1996). Personal communication. Sandia National Laboratories.

Clark, N.H. (1995). "Emerging Technologies." Chapter 7 in Power Sources Manufacturer's Association R\&D Subcommittee Report on Capacitors. Los Angeles, CA: Power Sources Manufacturer's Association. 
Clark, N.H.; W.E. Baca (1993). Characteristics and Development Report for the MC4169 DoubleLayer Capacitor Assembly. Albuquerque, NM: Sandia National Laboratories. SAND91-1818.

Conway, B. (1996). Personal communication. University of Ottawa.

Conway, B.E. (1994). "The Electrolyte Factor in Supercapacitor Design and Performance: Conductivity, Ion-Pairing and Solvation." Proceedings of the Fourth International Seminar on Double Layer Capacitors and Similar Energy Storage Devices. December 12-14, 1994. Deerfield Beach, Florida. Boca Raton, FL: Florida Educational Seminars Inc.

Daniels, E. (1996). Personal communication. Argonne National Laboratory.

Davis, B. (1996). Personal communication. General Electric, Inc.

Delnick, F. (1996). Personal communication. IMRA America, Inc.

Doughty, D. (1996). Personal communication. Sandia National Laboratories, New Mexico.

Eisenmann, E.T. (1995). Design Rules and Reality Check for Carbon-Based Ultracapacitors. SAND95-0671 • UC-400. Albuquerque, NM: Sandia National Laboratories.

Electric Power Research Institute (1995). Personnel Protection Systems for Electric Vehicle Charging Circuits. TR-105939. Prepared by Underwriters Laboratories Inc. Palo Alto, CA: Electric Power Research Institute.

Evans, D.A. (1996). Personal communication. Evans Capacitors Company.

Evans, D.A. (1994). "A Forty-Kilojoule Carbon Double-Layer Capacitor." Proceedings of the Thirty-Sixth Power Sources Conference. June 6-9, 1994. Cherry Hill, New Jersey. Fort Monmouth, NJ: U.S. Army Research Laboratory.

Evans, D.A. (1991). "Gas Generation in Carbon Double-Layer Capacitors." Proceedings of the First International Seminar on Double Layer Capacitors and Similar Energy Storage Devices. December 1991. Deerfield Beach, Florida. Boca Raton, FL: Florida Educational Seminars Inc.

Farahmandi, C.J.; E. Blank; D. Hileman; J. Dispennette; K. Lambert (1994) "Optimization of Carbon Fibers Used in Electrochemical Capacitors for Electric Vehicle Applications." Proceedings of the Thirty-Sixth Power Sources Conference. June 6-9, 1994. Cherry Hill, New Jersey. Fort Monmouth, NJ: U.S. Army Research Laboratory.

Farahmandi, C.J.; E. Blank (1994) "Bipolar Electrochemical Capacitors Based on Organic Electrolytes for Electric Vehicle Applications." Proceedings of the Fourth International Seminar on Double Layer Capacitors and Similar Energy Storage Devices. December 4-6, 1994. Deerfield Beach, Florida. Boca Raton, FL: Florida Educational Seminars Inc. 
Federal Register (1992). 57 Federal Register 31576.

Federal Register (1993). 58 Federal Register 63941.

Hair, L. (1996). Personal communication. Sandia National Laboratories, New Mexico.

Hall, Jr., R.M.; R.E. Schwartz; N.S. Bryson; R.C. Davis, Jr.; B.G. Donohue (1993). RCRA Hazardous Wastes Handbook. Rockville, MD: Govemment Institutes, Inc.

Haskins, H. (1996). Personal communication. Ford Motor Company.

Hausman, J. (1996). Personal communication. NEC Corp.

Horovitz, Z. (1996). Personal communication. Federal Fabrics-Fibers, Inc.

Horovitz, Z. (1995). Active Carbon Fibers for Electrochemical Capacitor. Wolsky, S.P., and N. Marincic, sponsors (1995). Proceedings of the Fifth International Seminar on Double Layer Capacitors and Similar Energy Storage Devices. December 4-6, 1995. Deerfield Beach, Florida. Boca Raton, FL: Florida Educational Seminars Inc.

HSDB (Hazardous Substances Data Bank) (1996). Information obtained from the National Library of Medicine online on May 24, 1996.

Innocenti, G. (1996). Personal communication. Cesiwid, Inc.

Isaacson, M. (1996). Personal communication. Lockheed-Martin.

J.T. Baker Inc. (1994a). Material Safety Data Sheet for Propylene Carbonate. Obtained from the Canadian Centre for Occupational Health and Safety. Phillipsburg, NJ: J.T. Baker Inc.

J.T. Baker Inc. (1994b). Material Safety Data Sheet for Diethyl Carbonate. Obtained from the Canadian Centre for Occupational Health and Safety. Phillipsburg, NJ: J.T. Baker Inc.

Johnson, G. (1996). Personal communication. Lawrence Livermore National Laboratory, Califomia.

Johnson Matthey (1991a). Material Safety Data Sheet for Tetraethylammonium Hexafluorophosphate. Ward Hill, MA: Johnson Matthey.

Johnson Matthey (1991b). Material Safety Data Sheet for Tetraethylammonium Tetrafluoroborate. Ward Hill, MA: Johnson Matthey.

Johnson Matthey (1985a). Material Safety Data Sheet for Tetrabutylammonium Tetrafluoroborate. Ward Hill, MA: Johnson Matthey. 
Johnson Matthey (1985b). Material Safety Data Sheet for Tetramethylammonium Hexafluorophosphate. Ward Hill, MA: Johnson Matthey.

Keolian, G. (1996). Personal communication. University of Michigan.

Koch, V. (1996). Personal communication. Covalent, Inc.

Leiby, R.; M. Bricker; R. Spitz (1995). "The East Penn Process for Recycling Sulfuric Acid from Lead Acid Batteries." Proceedings of the Third International Symposium on Recycling of Metals and Engineered Materials, Point Clear, Alabama, November 12-15, 1995. Warrendale, PA: Minerals, Metals, and Materials Society.

Lewis, R.J. (1992). Sax's Dangerous Properties of Industrial Materials. Eighth Edition. Volumes 1-3. New York: Van Nostrand Reinhold.

MacArthur, D. (1996). Personal communication. Chemac International Corporation, Inc.

Mathison, S. (1996). Personal communication. Honda.

Mayer, S.T. (1996). Personal communication. Polystor Corp.

Mayer, S.T; R.W. Pekala; J.L. Kaschmitter. (1993). "The Aerocapacitor: An Electrochemical Double-Layer Energy-Storage Device." Journal of the Electrochemical Society 140: 446-451.

McLaughlin, W. (1996). Personal communication. Toxco, Inc.

Miller, J. (1996). Personal communication. JME, Inc.

Moore, L. (1996). Personal communication. Mitsubishi.

Murphy, T.C. (1997). Personal communication. Idaho National Engineering Laboratory.

Murphy, T.C.; R.B. Wright; R.A.; Sutula (1996). "Performance of Electrochemical Capacitors." Proceedings of the Fifth International Seminar on Double Layer Capacitors and Similar Energy Storage Devices. December 4-6, 1995. Deerfield Beach, Florida. Boca Raton, FL: Florida Educational Seminars Inc.

NEC Corp. (1995). NEC Capacitors Data Book. Mountain View, CA: NEC Corporation.

Okijima, J. (1996). Personal communication. Panasonic.

OSHA (1995). 29 Code of Federal Regulations 1910.1000. "Table Z-1. Limits for Air Contaminants." 
Patty's Industrial Hygiene and Toxicology (Patty's) (1986). G.D. Clayton and F.E. Clayton, eds. New York: John Wiley \& Sons, Inc.

Patty's Industrial Hygiene and Toxicology (Patty's) (1981). G.D. Clayton and F.E. Clayton, eds. New York: John Wiley \& Sons, Inc.

Pekala, R.W. (1989). "Organic Aerogels from the Polycondensation of Resorcinol with Formaldehyde." Journal of Material Science 24: 3221-3227.

PPG Industries, Inc. (1994). Material Safety Data Sheet for Dimethyl Carbonate. Pittsburgh, PA: PPG Industries, Inc.

Raistrick, I.D. (1993). "Electrochemical Capacitors." Chapter 7 in Electrochemistry of Semiconductors and Electronics. Park Ridge, NJ: Noyes Publications.

Schutz, J. (1996). Personal communication. Nissan.

Sigma Chemical Company (1996a). Material Safety Data Sheet for Tetrabutylammonium Tetrafluoroborate. St. Louis, MO: Sigma Chemical Company.

Sigma Chemical Company (1996b). Material Safety Data Sheet for Tetraethylammonium Hexafluorophosphate. St. Louis, MO: Sigma Chemical Company.

Sigma-Aldrich Corporation. Material Safety Data Sheet for Dimethyl Carbonate. Milwaukee, WI: Sigma-Aldrich Corporation.

Sigma-Aldrich Corporation (1992). Material Safety Data Sheet for Dimethoxyethane. Milwaukee, WI: Sigma-Aldrich Corporation.

Smith, D. (1996). Personal communication. Sony.

Society of Automotive Engineers (1996). "Recommended Practice for Electric and Hybrid Electric Vehicle Battery Systems Crash Integrity Testing." J1766, February 1, 1996. Warrendale, PA: Society of Automotive Engineers.

Thorne, D.J. (1985). "Manufacture of Carbon Fiber from PAN." In Handbook of Composites, edited by W. Watt and B.V. Perov. New York: Elsevier Science Publishers.

Tran, T. (1996). Personal communication. Sandia National Laboratories, New Mexico.

Ue, M. (1994). "Mobility and Ionic Association of Lithium and Quaternary Ammonium Salts in Propylene Carbonate and $\gamma$-Butyrolactone." Journal of the Electrochemical Society 141: 33363342. 
Wagner, C. (1996). Personal communication. Sandia National Laboratories, New Mexico.

Yoshida, A.; K. Imoto; H. Yoneda; A. Nishino (1992). "An Electric Double-Layer Capacitor with High Capacitance and Low Resistance." IEEE Transactions on Components, Hybrids, and Manufacturing Technology 15:133-138. 


\section{Appendix A. Hazardous Materials Transport Regulations}

\section{Introduction}

This appendix presents information on hazardous materials transportation regulations that may be useful in understanding how the regulations apply to electrochemical capacitors. This section presents the hazardous materials transport regulations' purpose, content, and regulatory systems. Domestic transportation requirements, an approach to determine domestic transportation requirements for electrochemical capacitors, and a brief description of the international regulatory authorities will be provided in subsequent sections. The Shipping Requirements section (see "Detemining Transportation Requirements") indicates how these regulations may apply to electrochemical capacitors.

Hazardous materials transport regulations have two goals: to identify articles or substances that pose an "unreasonable" risk to health, safety, and property when transported in commerce; and to prescribe measures to control these risks, so that transport can occur with low enough risk to the public. To identify materials that pose an unreasonable risk in transport, regulations contain definitions of hazards of concern in transport. Such hazards include, but are not limited to, explosiveness, flammability, toxicity, corrosiveness, reactivity with water, and oxidizing potential. Substances or articles with these characteristics are subject to regulation. A hazard classification system is used to classify items for transport. The hazard class corresponding to the primary hazard posed by the item is assigned to that item.

If a substance or article meets the definition of one or more of the hazard classes, then transportation regulations require that the person offering the material for transport or transporting the material assume the following responsibilities (among others):

- $\quad$ Fulfill minimum packaging standards

- Mark and label packages to identify the substance or article and the nature of the hazard

- Include required information on transport documentation to identify the substance or article transported, its hazard, the quantity being shipped, and (in some cases) the steps to take in the event of an incident involving the material

- Include a signed certification stating that all applicable requirements have been fulfilled

- Depending on the mode of transport involved (rail, highway, vessel, or aircraft), comply with specific requirements for loading, handling, and carrying the goods (e.g., identify vehicles that contain dangerous goods, and segregate incompatible goods). 
Transportation regulations also require training for persons involved in classifying hazardous materials, packaging, marking, labeling, and preparing shipping papers, and any other preparation of a consignment for shipping.

Transportation regulatory systems are based on United Nations (UN) recommendations. The UN Committee of Experts on the Transport of Dangerous Goods prepares these recommendations, and publishes them in Recommendations on the Transport of Dangerous Goods (UN Recommendations). The UN Recommendations promote uniformity in hazardous materials transport requirements at the global level and between various modes of transport. International air and sea transport requirements, as well as domestic hazardous materials transport regulations, are based on the UN Recommendations. Therefore, these regulations are consistent in their goals and contents, described above. For example, there is consistency in the identification of substances and articles that pose a risk in transport and in the requirements that apply. However, details of international and domestic regulatory standards may differ.

\section{Domestic Transportation Requirements}

The DOT Hazardous Materials Regulations (49 CFR 100-180) govern domestic or international transportation (or offering for transportation) of hazardous materials in the United States. These regulations apply to highway, rail, vessel, or aircraft transportation in the United States, including its territorial waters and airspace. A hazardous material is a "substance or material... which has been determined by the Secretary of Transportation to be capable of posing an unreasonable risk to health, safety, and property when transported in commerce..."

\section{Materials and Devices Forbidden in Transportation}

Certain materials or devices pose risks that are inherently unacceptable in transport, and are called "forbidden" materials in the DOT regulations (49 CFR 173.21). Forbidden materials may not be transported or offered for transport. The person transporting or offering an item for transport must determine if it is a forbidden material. Forbidden materials characteristics were described in the section "Mitigating Hazards of Forbidden Materials."

The evolution of heat and flarmmable gas is a forbidden material characteristic, but the regulations do not establish quantitative limits, so judgement must be used to determine what represents a dangerous quantity of heat or gas in the particular transportation situation.

\section{Hazardous Materials Criteria}

Code of Federal Regulations, Title 49, Chapter 173 defines hazard classes. The definitions generally include tests and criteria that may be used to determine if a material meets the definition. Transportation regulations apply to all materials that meet the definition of a hazard class, whether or not they are narned in the hazardous materials table. The table includes generic listings, based on hazard type, that may be used for materials not listed by name. The abbreviation "n.o.s." (not 
otherwise specified) signals that a listing is generic. For example, generic entries must be selected to correspond to the hazards and packing group of the material (e.g., "Corrosive liquids, n.o.s.").

\section{Hazardous Materials Table}

The Hazardous Materials Table lists materials considered hazardous in transportation (49 CFR 172.101). This table is used to determine applicable requirements. The listed materials include hazardous liquids, solids, and gases, as well as articles or devices that contain such hazardous materials. For each listed item, the table indicates the hazard class, the identification number, the section of the regulations that specifies required packaging, and other information such as hazard labeling requirements and quantity restrictions. The person offering the material for transportation must select the listed item that most closely describes the material and that has a hazard class corresponding to the hazard of the material.

\section{Hazard Communication and Packaging}

The hazardous materials table entry indicates the section in the regulations that provides information about required packaging, labeling, quantity restrictions, and other requirements. Other sections in the regulations state requirements for preparing the shipping papers; marking packages; placarding vehicles, rail cars, or freight containers; and other requirements.

\section{International Transportation Requirements}

The International Maritime Organization (IMO) promulgates international requirements applicable to the transport by vessel of hazardous materials (termed "dangerous goods" internationally). The International Civil Aviation Organization (ICAO) promulgates those applicable to transport by commercial aircraft. The IMO is a specialized agency of the $\mathrm{UN}$ responsible for developing standards and regulations to promote the safety of life and property at sea and to prevent pollution from ships. The International Maritime Dangerous Goods Code (IMDG Code) contains the IMO dangerous goods transport requirements. The Technical Instructions for the Safe Transport of Dangerous Goods by Air (Technical Instructions) contains the ICAO dangerous goods transport requirements. Each regulatory standard is based on the UN Recommendations, but may contain additional requirements for the particular mode of transport.

The IMDG Code and the Technical Instructions are fundamentally consistent with DOT regulations, because all three are based on the UN Recommendations. However, the international regulatory authorities may need to be consulted directly if questions arise about applying appropriate international transport standards. 
Public reporting burden for this collection of information is estimated to average 1 hour per response, including the time for reviewing instructions, searching existing data sources, gathering and maintaining the data needed, and completing and reviewing the collection of information. Send comments regarding this burden estimate or any other aspect of this collection of information, including suggestions for reducing this burden, to Washington Headquarters Services, Directorate for Information Operations and Reports, 1215 Jefferson Davis Highway, Suite 1204, Arlington, VA 22202-4302, and to the Office of Management and Budget,. Paperwork Reduction Project (0704-0188), Washington, DC 20503.

\begin{tabular}{|l|l|l|l}
\hline 1. AGENCY USE ONLY (Leave blank) & $\begin{array}{l}\text { 2. REPORT DATE } \\
\text { April } 1997\end{array}$ & $\begin{array}{l}\text { 3. REPORT TYPE AND DATES COVERED } \\
\text { technical report }\end{array}$ \\
\hline
\end{tabular}

4. TITLE AND SUBTITLE

Current Status of Environmental, Health, and Safety Issues of Electrochemical Capacitors for Advanced Vehicle Applications
5. FUNDING NUMBERS AS015702

6. $A U T H O R(S)$

L. Vimmerstedt and C. Hammel

7. PERFORMING ORGANIZATION NAME(S) AND ADDRESS(ES)

National Renewable Energy Laboratory

1617 Cole Boulevard

Golden, Colorado 80401-3393

8. PERFORMING ORGANIZATION REPORT NUMBER

TP-460-22452

DE97000243

9. SPONSORING/MONITORING AGENCY NAME(S) AND ADDRESS(ES)

U.S. Department of Energy

1000 Independence Ave., SW

Washington, DC 20585

10. SPONSORING/MONITORING AGENCY REPORT NUMBER

11. SUPPLEMENTARY NOTES

12a. DISTRIBUTION/AVAILABILITY STATEMENT

National Technical Information Service

U.S. Department of Commerce

5285 Port Royal Road

Springfield, VA 22161 12b. DISTRIBUTION CODE

UC 1501

13. ABSTRACT (Maximum 200 words)

This report examines the environmental, health, and safety issues associated with the use of electrochemical capacitors in advanced vehicles. Current development efforts target using electrochemical capacitors to provide power assists in hybrid electric vehicles (HEVs). HEVs could help meet the energy and environmental goals for national transportation because of their improved fuel efficiency and emissions compared with conventional vehicles. These capacitors might be used in HEVs because of their high power capability and long life. Understanding environmental, health, and safety issues associated with electrochemical capacitors in advanced vehicles is an important step toward commercialization.

14. SUBJECT TERMS electrochemical capacitors; advanced vehicles; environmental, health and safety

15. NUMBER OF PAGES

54

16. PRICE CODE
17. SECURITY CLASSIFICATION OF REPORT unclassified
18. SECURITY CLASSIFICATION OF THIS PAGE unclassified
19. SECURITY CLASSIFICATION OF ABSTRACT unclassified
20. LIMITATION OF ABSTRACT

UL 